\title{
SPECIES COMPOSITION AND SEASONAL VARIATION OF PERACARIDS (CRUSTACEA: PERACARIDA) OF THE ISTANBUL STRAIT (TURKEY)
}

\author{
MÜLAYIM, A. \\ Department of Biology, Faculty of Science, Istanbul University, 34134 Vezneciler, Istanbul, \\ Turkey \\ (e-mail: aysegulm@istanbul.edu.tr; phone:+90-532-597-8093) \\ (Received $18^{\text {th }}$ Aug 2020; accepted $22^{\text {nd }}$ Oct 2020)
}

\begin{abstract}
The Istanbul Strait connects the Black Sea with the Sea of Marmara and it has a two-layered water system. In this study, we determined the diversity of the Peracarid Crustacean fauna and the ecological characteristics of the area. The data produced in this study revealed 76 peracarid species in the Istanbul Strait, of which five species (Animoceradocus semiserratus (Spence Bate.1862), Echinogammarus stocki G. Karaman, 1973, Leptocheirus bispinosus Norman, 1908, Cymodoce spinosa (Risso, 1816), Gnathia dentata (G. O. Sars, 1872)) were reported for the first time in the Sea of Marmara. The physicochemical properties of the seawater as well as total organic and inorganic carbon, and mud percentages of the sediment were analyzed at the sampling stations. In these stations, no significant relationship was determined between temperature, salinity, dissolved oxygen parameters and species or individual numbers. However, a positive relationship was found between the mud percentage and species and individual numbers. In contrast, at the hard bottom stations the number of individuals was positively associated with temperature and negatively with dissolved oxygen.
\end{abstract}

Keywords: Crustacea, species diversity, hard and soft bottom habitats, ecology, Sea of Marmara

\section{Introduction}

The Istanbul Strait (also known as the Bosphorus) connects the Black Sea with the Sea of Marmara. This strait and the Dardanelles are located at opposite ends in the Sea of Marmara. These straits create a series of passages connecting the Aegean and Mediterranean (via the Dardanelles) to the Sea of Marmara, and ultimately the Black Sea via the Istanbul Strait (Beşiktepe et al., 1995). The Istanbul Strait, like the Sea of Marmara has a two-layered water system. The low-salinity waters of the Black Sea (17.86 PSU) are transported to the Mediterranean Sea through the straits, while the salty Mediterranean waters (37.3 PSU) move as underflow toward the Black Sea (Ünlüata et al., 1990; Orhon, 1995).

The Istanbul Strait has long coastal sides, which are both residential and social facilities are highly concentrated (Usluer and Alkan, 2016). Moreover, the Istanbul Strait is the narrowest strait used for international navigation in the world and the maritime traffic is dense (Birpinar et al., 2009). This means that pollution by sea is visible in the strait. In addition, as a large metropolis, Istanbul is a focal point of terrestrial pollution (Orhon, 1995). Therefore, monitoring of marine fauna and flora of this region is of critical importance.

The superorder Peracarida is a major component of marine benthic ecosystems and has a regionally high population density (Thiel and Hinojosa, 2009). They also dominate other groups of organisms in terms of individual number and species diversity (GuerraGarcía et al., 2009). Some species are highly sensitive indicators due to their predominance and sensitivity to pollutants and are frequently used as bioindicators in biological monitoring studies (Chintiroglou et al., 2004; Dauvin and Ruellet, 2007). 
Therefore, the monitoring of peracarid fauna is useful for understanding the effects of ecological changes on benthic fauna (Moreira et al., 2008).

Studies involving peracarids in the Istanbul Strait begin with Sowinsky (1897). Subsequent studies were conducted by Demir (1952), Caspers (1968), Băcescu (1982), Topaloğlu and Kihara (1993), Balkıs et al. (2002), Uysal et al. (2002), Kalkan et al. (2006), Kalkan et al. (2007), Aslan-Cihangir and Panucci-Papadopolou (2011), Öktener, Trilles (2004) and Bakir et al. (2016). Balkis et al. (2016) conducted an extensive review of studies on Malacostraca crustaceans in the Turkish Strait System in which they listed 274 species of peracarid crustacean.

This study determined peracarid species diversity in the Istanbul Strait and explored its relationship with several environmental variables. Moreover, this study will elucidate the seasonal variation of peracarid biodiversity.

\section{Materials and methods}

\section{Sampling}

Sampling was performed seasonally between 22 and 23 July 2015, 27 and 28 October 2015, 1-4 February 2016 and 1-9 May 2016 at 34 stations (Table 1; Fig. 1). Peracarid samples were collected from the hard bottom with a $20 \times 20 \mathrm{~cm}$ quadrat using a spatula, and a Van Veen Grab with $0.1 \mathrm{~m}^{2}$ sampling capacity from the soft bottom. Three replicates were collected from each station. Benthic samples were sieved with $0.5 \mathrm{~mm}$ mesh and stored in a $4 \%$ formaldehyde solution prepared with seawater. Hard bottom sampling was performed at 13 stations $(0.5 \mathrm{~m})$ near the shores of the Istanbul Strait at sites unaltered by shore filling. Appropriate stations for sampling are difficult to find due to the extensive coastal filling of the strait. Soft bottom samples were collected from 21 stations at 11 localities in the Istanbul Strait and samples were taken from two depths $(18.2 \mathrm{~m}$ and $36.4 \mathrm{~m})$. As mentioned in the introduction, there is a two-layered water system in the Sea of Marmara. The upper water layer is the Black Sea (low salinity) and the lower water layer is the Mediterranean Sea (high salinity) and this two layer don't with each other due to different densities of salinity, but form a salinity intermediate water (halocline) at $25 \mathrm{~m}$ depth of the Sea of Marmara (Beşiktepe et al., 1995). Depths (18.2 m and $36.4 \mathrm{~m}$ ) were chosen to ensure sampling captured faunal differences between the Black Sea and Mediterranean waters. These two depths have different salinity and dissolved oxygen conditions.

\section{The physicochemical parameters}

Temperature, dissolved oxygen, and salinity values of the seawater were measured using a YSI brand multiparameter device. Sediment samples were collected with a plastic spoon from the upper layer of sediment at the depths specified above, placed into nylon bags and stored at $-20{ }^{\circ} \mathrm{C}$ in a deep freezer. Since hard bottom samples were taken from algae and mussel rocks, mud samples were not available for total organic carbon (TOC) and total inorganic carbon (TIC) analyses. Thus, TOC, TIC and mud percentage values were obtained only for soft bottom surface sediment samples. TOC and TIC analyses were performed according to the Walkey-Blake method (Gaudette et al., 1974; Loring and Rantala, 1992). The mud percentage of sediment samples for the stations studied were determined according to the Galehouse (1971) and Mc Manus (1991) methods. 
Table 1. Stations, coordinates, depth, and biotope properties of the sampling stations in the Istanbul Strait

\begin{tabular}{|c|c|c|c|c|c|c|}
\hline Station & Station area & Latitude & Longitude & Depth (m) & Substrate type & Sampling device \\
\hline 1 & Garipçe Shore & $41^{\circ} 12^{\prime} 799^{\prime \prime}$ & $29^{\circ} 06^{\prime} 564^{\prime \prime}$ & 0.5 & Hard Bottom & Quadrat \\
\hline 2 & Rumeli Kavağ & $41^{\circ} 10^{\prime} 670^{\prime \prime}$ & $29^{\circ} 04^{\prime} 451^{\prime \prime}$ & 0.5 & Hard Bottom & Quadrat \\
\hline 3 & Sariyer Shore & $41^{\circ} 09^{\prime} 792^{\prime \prime}$ & $29^{\circ} 02^{\prime} 935^{\prime \prime}$ & 0.5 & Hard Bottom & Quadrat \\
\hline 4 & Tarabya Shore & $41^{\circ} 08^{\prime} 202^{\prime \prime}$ & $29^{\circ} 03^{\prime} 524^{\prime \prime}$ & 0.5 & Hard Bottom & Quadrat \\
\hline 5 & Baltalimanı Shore & $41^{\circ} 05^{\prime} 820^{\prime \prime}$ & $29^{\circ} 03^{\prime} 246^{\prime \prime}$ & 0.5 & Hard Bottom & Quadrat \\
\hline 6 & Beşiktaş Shore & $41^{\circ} 02^{\prime} 499^{\prime \prime}$ & $29^{\circ} 00^{\prime} 623^{\prime \prime}$ & 0.5 & Hard Bottom & Quadrat \\
\hline 7 & Anadolufeneri Shore & $41^{\circ} 12^{\prime} 878^{\prime \prime}$ & $29^{\circ} 09^{\prime} 131^{\prime \prime}$ & 0.5 & Hard Bottom & Quadrat \\
\hline 8 & Poyraz Shore & $41^{\circ} 12^{\prime} 296^{\prime \prime}$ & $29^{\circ} 07^{\prime} 903^{\prime \prime}$ & 0.5 & Hard Bottom & Quadrat \\
\hline 9 & Anadolukavağı Shore & $41^{\circ} 10^{\prime} 3491^{\prime \prime}$ & $29^{\circ} 05^{\prime} 308^{\prime \prime}$ & 0.5 & Hard Bottom & Quadrat \\
\hline 10 & Paşabahçe Shore & $41^{\circ} 07^{\prime} 302^{\prime \prime}$ & $29^{\circ} 05^{\prime} 846^{\prime \prime}$ & 0.5 & Hard Bottom & Quadrat \\
\hline 11 & Anadoluhisarı Shore & $41^{\circ} 04^{\prime} 788^{\prime \prime}$ & $29^{\circ} 03^{\prime} 899^{\prime \prime}$ & 0.5 & Hard Bottom & Quadrat \\
\hline 12 & Kuleli Shore & $41^{\circ} 03^{\prime} 613^{\prime \prime}$ & $29^{\circ} 03^{\prime} 164^{\prime \prime}$ & 0.5 & Hard Bottom & Quadrat \\
\hline 13 & Kuzguncuk Shore & $41^{\circ} 02^{\prime} 283^{\prime \prime}$ & $29^{\circ} 01^{\prime} 873^{\prime \prime}$ & 0.5 & Hard Bottom & Quadrat \\
\hline 14 & Garipçe 1 & $41^{\circ} 12^{\prime} 828^{\prime \prime}$ & $29^{\circ} 06^{\prime} 771^{\prime \prime}$ & 18.2 & Soft Bottom & Van Veen Grab \\
\hline 15 & Garipçe 2 & $41^{\circ} 12^{\prime} 663^{\prime \prime}$ & $29^{\circ} 06^{\prime} 907^{\prime \prime}$ & 36.4 & Soft Bottom & Van Veen Grab \\
\hline 16 & İstinye 1 & $41^{\circ} 06^{\prime} 766^{\prime \prime}$ & $29^{\circ} 03^{\prime} 619^{\prime \prime}$ & 18.2 & Soft Bottom & Van Veen Grab \\
\hline 17 & İstinye 2 & $41^{\circ} 06^{\prime} 670^{\prime \prime}$ & $29^{\circ} 03^{\prime} 772^{\prime \prime}$ & 36.4 & Soft Bottom & Van Veen Grab \\
\hline 18 & Bebek 1 & $41^{\circ} 04^{\prime} 676^{\prime \prime}$ & $29^{\circ} 02^{\prime} 941^{\prime \prime}$ & 18.2 & Soft Bottom & Van Veen Grab \\
\hline 19 & Bebek 2 & $41^{\circ} 04^{\prime} 717^{\prime \prime}$ & $29^{\circ} 03^{\prime} 056^{\prime \prime}$ & 36.4 & Soft Bottom & Van Veen Grab \\
\hline 20 & Ortaköy 1 & $41^{\circ} 02^{\prime} 824^{\prime \prime}$ & $29^{\circ} 01^{\prime} 557^{\prime \prime}$ & 18.2 & Soft Bottom & Van Veen Grab \\
\hline 21 & Ortaköy 2 & $41^{\circ} 02^{\prime} 795^{\prime \prime}$ & $29^{\circ} 01^{\prime} 609^{\prime \prime}$ & 36.4 & Soft Bottom & Van Veen Grab \\
\hline 22 & Karaköy 1 & $41^{\circ} 01^{\prime} 428^{\prime \prime}$ & $28^{\circ} 58^{\prime} 822^{\prime \prime}$ & 18.2 & Soft Bottom & Van Veen Grab \\
\hline 23 & Karaköy 2 & $41^{\circ} 01^{\prime} 420^{\prime \prime}$ & $28^{\circ} 58^{\prime} 835^{\prime \prime}$ & 36.4 & Soft Bottom & Van Veen Grab \\
\hline 24 & Salacak & $41^{\circ} 01^{\prime} 020^{\prime \prime}$ & $29^{\circ} 00^{\prime} 202^{\prime \prime}$ & 18.2 & Soft Bottom & Van Veen Grab \\
\hline 25 & Çengelköy 1 & $41^{\circ} 02^{\prime} 962^{\prime \prime}$ & $29^{\circ} 03^{\prime} 051^{\prime \prime}$ & 18.2 & Soft Bottom & Van Veen Grab \\
\hline 26 & Çengelköy 2 & $41^{\circ} 03^{\prime} 015^{\prime \prime}$ & $29^{\circ} 03^{\prime} 027^{\prime \prime}$ & 36.4 & Soft Bottom & Van Veen Grab \\
\hline 27 & Anadoluhisarı 1 & $41^{\circ} 04^{\prime} 760^{\prime \prime}$ & $29^{\circ} 03^{\prime} 844^{\prime \prime}$ & 18.2 & Soft Bottom & Van Veen Grab \\
\hline 28 & Anadoluhisarı 2 & $41^{\circ} 04^{\prime} 736^{\prime \prime}$ & $29^{\circ} 03^{\prime} 803^{\prime \prime}$ & 36.4 & Soft Bottom & Van Veen Grab \\
\hline 29 & Paşabahçe 1 & $41^{\circ} 07^{\prime} 255^{\prime \prime}$ & $29^{\circ} 05^{\prime} 598^{\prime \prime}$ & 18.2 & Soft Bottom & Van Veen Grab \\
\hline 30 & Paşabahçe 2 & $41^{\circ} 07^{\prime} 216^{\prime \prime}$ & $29^{\circ} 05^{\prime} 322^{\prime \prime}$ & 36.4 & Soft Bottom & Van Veen Grab \\
\hline 31 & Anadolukavağ 1 & $41^{\circ} 10^{\prime} 375^{\prime \prime}$ & $29^{\circ} 05^{\prime} 273^{\prime \prime}$ & 18.2 & Soft Bottom & Van Veen Grab \\
\hline 32 & Anadolukavağ 2 & $41^{\circ} 10^{\prime} 288^{\prime \prime}$ & $29^{\circ} 05^{\prime} 222^{\prime \prime}$ & 36.4 & Soft Bottom & Van Veen Grab \\
\hline 33 & Keçilik 1 & $41^{\circ} 11^{\prime} 841^{\prime \prime}$ & $29^{\circ} 07^{\prime} 102^{\prime \prime}$ & 18.2 & Soft Bottom & Van Veen Grab \\
\hline 34 & Keçilik 2 & $41^{\circ} 11^{\prime} 846^{\prime \prime}$ & $29^{\circ} 07^{\prime} 037^{\prime \prime}$ & 36.4 & Soft Bottom & Van Veen Grab \\
\hline
\end{tabular}

\section{Statistical methods}

The Soyer (1970) frequency index (Fi) and the dominance index (Di) formula of BellanSantini (1969), respectively, were used to determine the frequency and dominance of peracarid species in the study area. The species were classified into three groups: Constant ( $\mathrm{Fi} \geq 50 \%)$, Common $\left(50 \%>\mathrm{F}_{\mathrm{i}} \geq 25 \%\right)$, and Rare $\left(\mathrm{F}_{\mathrm{i}}<25 \%\right)$, according to their frequency indexes. The Bray-Curtis similarity index and multi-dimensional scaling (MDS) methods were used to determine similarities between sampling stations and to resolve regional 
distribution models, respectively. $\mathrm{R}$ value was calculated by using ANOSIM (similarity analysis) in order to test the significant differences between the groups formed in each season for both substrates. After bulk analysis, the similarities or differences within each group and the percentage contribution of each species to the similarities and differences among the resulting groups were identified using SIMPER analysis. We used Primer 6 program for these analyses (Clarke and Warwick, 2001). Relationships with abiotic parameters were revealed using the Spearman rank correlation coefficient method with IBM Statistics Version 21 (Siegel, 1956). We calculated the Shannon-Weaver Diversity Index $\left(H^{\prime}\right)$ using a composite of number of species and individuals at the sampling stations (Zar, 1984).

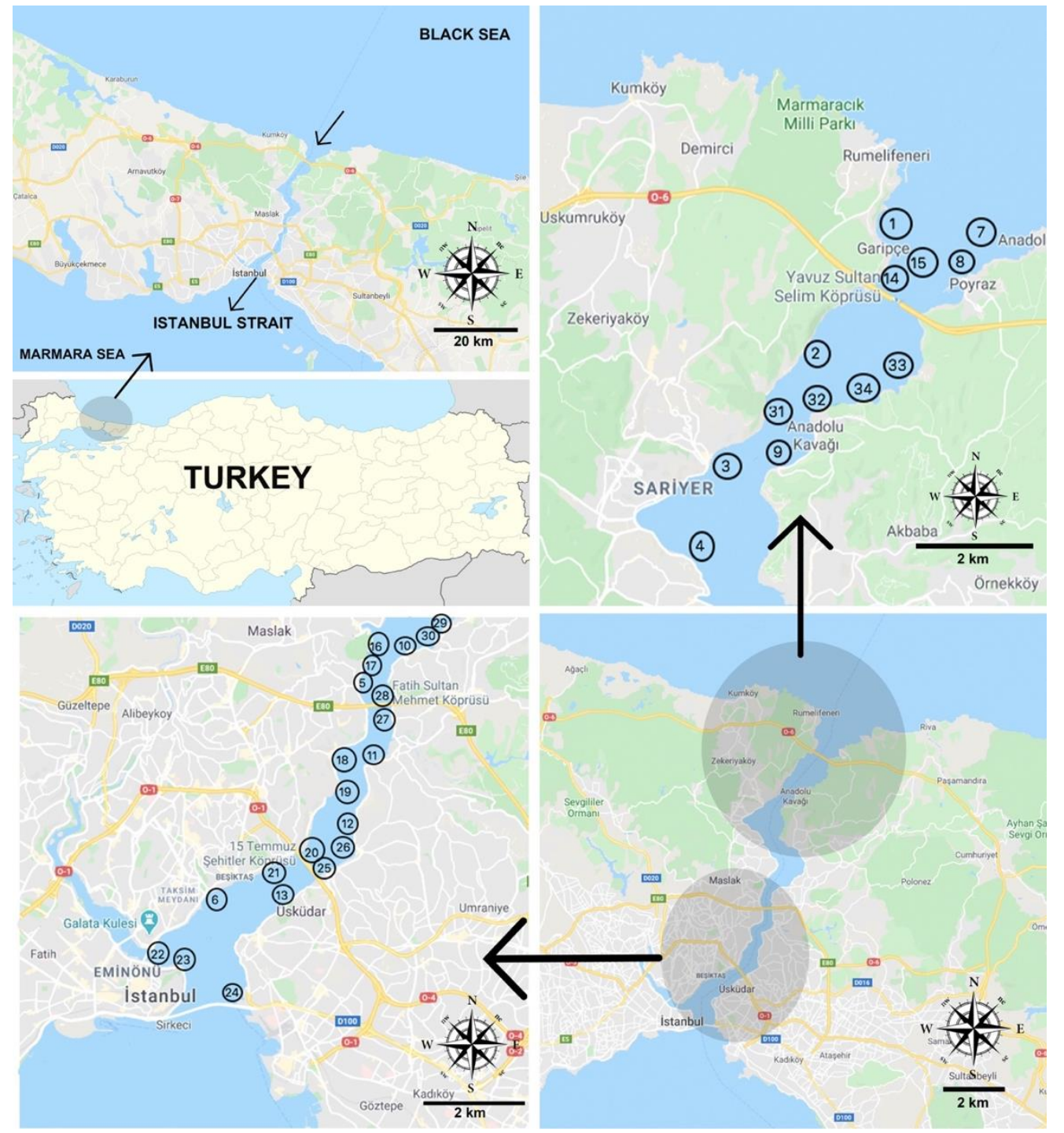

Figure 1. Map of the sampling stations. Hard bottom station: 1. Garipçe Shore 2. Rumeli Kavağl Shore 3. Sarlyer Shore 4. Tarabya Shore 5. Baltalimanı Shore 6. Beşiktaş Shore 7.

Tarabya Shore 8. Poyraz Shore 9. Anadolukavağı Shore 10. Paşabahçe Shore 11.

Anadoluhisart Shore 12. Kuleli Shore 13. Kuzguncuk Shore. Soft bottom station: 14. Garipçe 1 15. Garipçe 2 16. Istinye 1 17. Istinye 2 18. Bebek 1 19. Bebek 2 20. Ortaköy 121. Ortaköy 2 22. Karaköy 1 23. Karaköy 2 24. Salacak 25. Çengelköy 1 26. Çengelköy 2 27. Anadoluhisarı 1 28. Anadoluhisarı 2 29. Paşabahçe 1 30. Paşabahçe 2. 31. Anadolukavağ 1 32. Anadolukavă̆l 2 33. Keçilik 1 34. Keçilik 2 


\section{Results}

This study identified 76 peracarid crustacean species representing five orders (Table 2). Animoceradocus semiserratus (Spence Bate, 1862), Echinogammarus stocki G. Karaman, 1970, Leptocheirus bispinosus Norman, 1908, Cymodoce spinosa (Risso, 1816), and Gnathia dentata (G. O. Sars, 1872) were new records for the Sea of Marmara. Examining the taxonomic distribution, we observed that most of the species obtained across all samples belong to the order Amphipoda (Fig. 2). Species belonging to the orders Amphipoda, Isopoda, and Tanaidacea were found in hard bottom samples, but not species belonging to the orders Mysidacea or Cumacea. Amphipod species are dominant on the soft bottom, but peracarid species of Isopoda, Cumacea, Tanaidacea, and Mysidacea were also found, in order of decreasing occurrence.

\section{Hard Bottom Species}

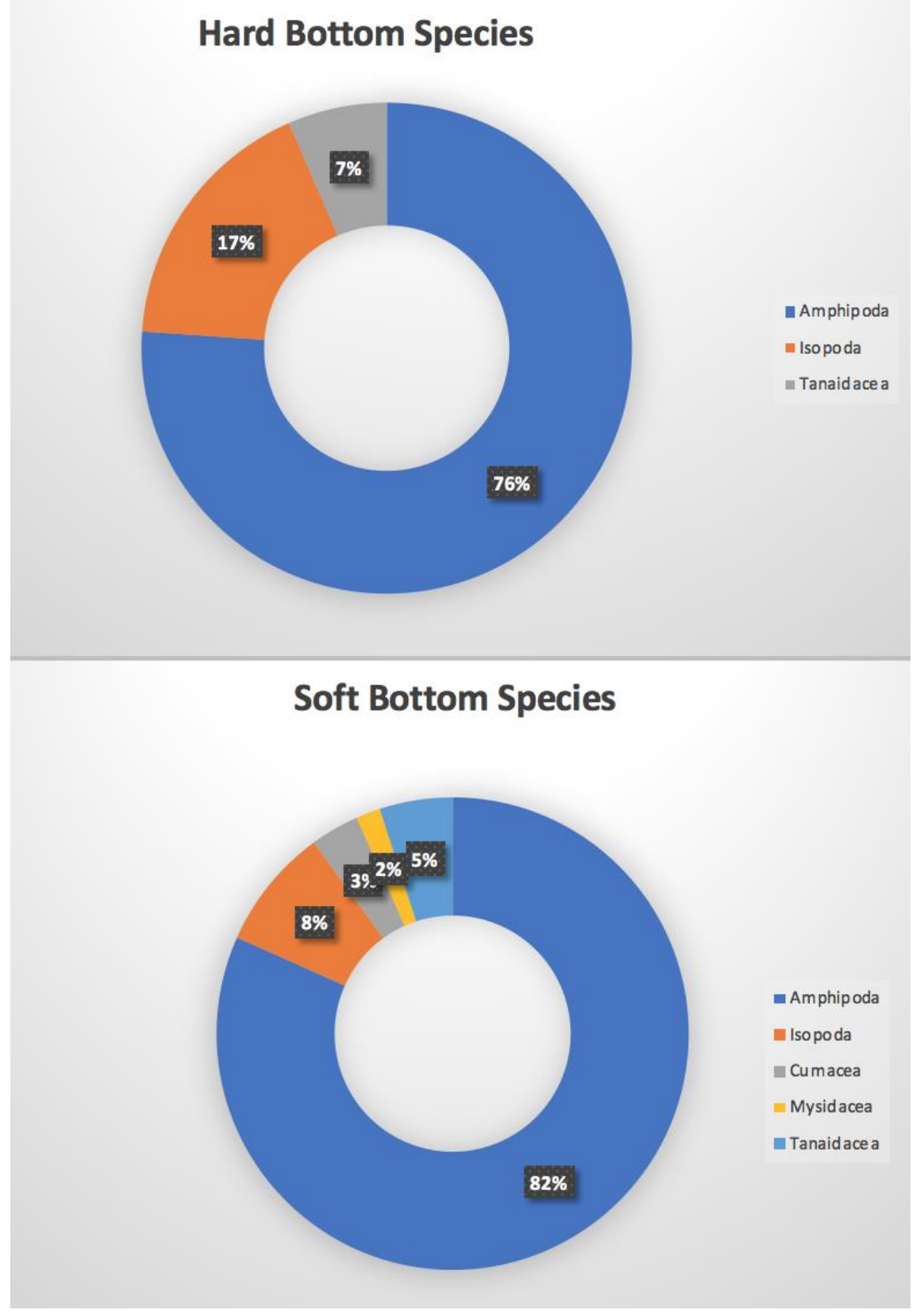

Figure 2. The distribution of species by orders 
Table 2. Peracarid Crustacean species of the Istanbul Strait and average individual numbers. Habitat type: Hs: Hard substratum, Mytilus with algae Ss: Soft substratum

\begin{tabular}{|c|c|c|c|c|}
\hline SPECIES & SUMMER & AUTUMN & WINTER & SPRING \\
\hline \multicolumn{5}{|l|}{ AMPHIPODA } \\
\hline Ampelisca diadema (Costa. 1853) & Ss:7 & & & Ss:3 \\
\hline Ampelisca multispinosa Bellan-Santini \& Kaim-Malka. 1977 & & & & Ss:3 \\
\hline Ampelisca pseudosarsi Bellan-Santini \& Kaim-Malka. 1977 & Ss:3 & & & \\
\hline Amphilochus brunneus Della Valle. 1893 & & Ss:33 & Ss:23.3 & Ss: 43 \\
\hline Ampithoe ramondi Audouin. 1826 & Hs:75039.9 & Hs: 586.7 & $\begin{array}{c}\text { Hs: } 46.7 \\
\text { Ss: } 6.6\end{array}$ & Hs:540 \\
\hline *Animoceradocus semiserratus (Spence Bate.1862) & Ss:27 & & & \\
\hline Aora gracilis (Spence Bate. 1857) & Hs:6.7 & & Hs:6.7 & \\
\hline Apherusa chiereghinii Giordani- Soika. 1949 & & & & Hs:200 \\
\hline Apherusa mediterranea Chevreux. 1911 & & & & Hs: 106.7 \\
\hline Apocorophium acutum (Chevreux. 1908) & $\begin{array}{c}\text { Hs:3853.3 } \\
\text { Ss:319 } \\
\end{array}$ & $\begin{array}{l}\text { Hs:13.3 } \\
\text { Ss:2094 } \\
\end{array}$ & $\begin{array}{c}\text { Hs:6 } \\
\text { Ss:263.2 } \\
\end{array}$ & $\begin{array}{c}\text { Hs: } 286.7 \\
\text { Ss: } 339 \\
\end{array}$ \\
\hline Apolochus picadurus (J.L. Barnard. 1962) & Ss: 10 & & & Ss:3 \\
\hline Caprella acanthifera Leach. 1814 & Ss:67 & Hs:333.3 & & $\begin{array}{c}\text { Hs:86.7 } \\
\text { Ss:7 }\end{array}$ \\
\hline Caprella danilevskii Czerniavski. 1868 & & Hs:6.7 & Ss:13.3 & \\
\hline Caprella rapax Mayer. 1890 & & Hs:26.7 & & \\
\hline Centraloecetes dellavallei (Stebbing. 1899) & Ss: 10 & & & \\
\hline Chelura terebrans Philippi. 1839 & & & & Ss:103 \\
\hline Colomastix pusilla Grube. 1861 & Ss: 17 & & & Ss:33 \\
\hline Cymadusa crassicornis (Costa. 1853) & & & & $\begin{array}{l}\text { H:13.3 } \\
\text { Ss: } 87\end{array}$ \\
\hline Deflexilodes gibbosus (Chevreux. 1888) & Ss:3 & & Ss:6.7 & \\
\hline Dexamine spiniventris (Costa. 1853) & Ss:3 & & & Hs:566.6 \\
\hline Dexamine spinosa (Montagu. 1813) & $\begin{array}{c}\text { Hs:6.6 } \\
\text { Ss:3 }\end{array}$ & Hs: 60 & Ss:3.3 & $\begin{array}{c}\text { Hs: } 513.3 \\
\text { Ss:3 }\end{array}$ \\
\hline Echinogammarus foxi (Schellenberg. 1928) & Hs: 3080 & Hs: 120 & Hs:20 & \\
\hline Echinogammarus olivii (H. Milne Edwards. 1830) & $\begin{array}{c}\text { Hs: } 58513.3 \\
\text { Ss: } 7\end{array}$ & Hs:946.7 & Hs:493.3 & $\begin{array}{c}\text { Hs: } 4366.7 \\
\text { Ss:6 }\end{array}$ \\
\hline Echinogammarus stocki G. Karaman. 1970 & & & Hs:66.7 & \\
\hline Elasmopus brasiliensis (Dana. 1855) & Hs:40 & & & \\
\hline Elasmopus pocillimanus (Spence Bate. 1862) & $\begin{array}{c}\text { Hs:58033.3 } \\
\text { Ss:3 }\end{array}$ & & & \\
\hline Ericthonius brasiliensis (Dana. 1853) & Ss:13 & Hs:13.3 & Hs:20 & Hs: 40 \\
\hline Gammarella fucicola (Leach. 1814) & Ss:16 & Ss:97 & Ss: 10 & Ss:97 \\
\hline Gammarus aequicauda (Martynov. 1931) & Hs: 173.3 & & Hs:6.7 & Hs:13.3 \\
\hline Gammarus crinicornis Stock. 1966 & Ss: 7 & & & \\
\hline Gitana sarsi Boeck. 1871 & & & & Ss:167 \\
\hline Protohyale (Protohyale) schmidtii (Heller, 1866) & $\begin{array}{c}\text { Hs: } 178600 \\
\text { Ss:36 }\end{array}$ & $\begin{array}{c}\text { Hs: } 44206.7 \\
\text { Ss: } 6\end{array}$ & $\begin{array}{c}\text { Hs: } 7246.7 \\
\text { Ss:6.6 }\end{array}$ & $\begin{array}{c}\text { Hs: } 29260 \\
\text { Ss:3 }\end{array}$ \\
\hline Jassa marmorata Holmes. 1905 & $\begin{array}{c}\text { Hs: } 11319.8 \\
\text { Ss:460 }\end{array}$ & $\begin{array}{c}\text { Hs:7826.7 } \\
\text { Ss:3 }\end{array}$ & Hs:2853.4 & $\begin{array}{c}\text { Hs: } 8753.2 \\
\text { Ss: } 20\end{array}$ \\
\hline Jassa ocia (Spence Bate. 1862) & $\begin{array}{c}\text { Hs:333.3 } \\
\text { Ss:4363 } \\
\end{array}$ & Ss: 873 & Ss: 113.3 & Ss:70 \\
\hline *Leptocheirus bispinosus Norman. 1908 & Ss:123 & Ss:146 & & \\
\hline Leptocheirus pilosus Zaddach. 1844 & & & Ss:66.7 & \\
\hline Maera grossimana (Montagu. 1808) & & & Ss:6.6 & \\
\hline Medicorophium rotundirostre (Stephensen. 1915) & Ss:3 & Ss:3 & & \\
\hline Megamphopus brevidactylus Myers. 1976 & & Ss:7 & & \\
\hline Megamphopus cornutus Norman. 1869 & Ss:7 & & & \\
\hline Melita palmata (Montagu. 1804) & $\begin{array}{c}\text { Hs: } 579.9 \\
\text { Ss:206 }\end{array}$ & Ss:103 & $\begin{array}{l}\text { Hs:13.4 } \\
\text { Ss:753.1 }\end{array}$ & $\begin{array}{l}\text { Hs:280 } \\
\text { Ss:558 }\end{array}$ \\
\hline
\end{tabular}




\begin{tabular}{|c|c|c|c|c|}
\hline Microdeutopus algicola Della Valle. 1893 & & Ss:3 & Ss:56.6 & Hs:26.7 \\
\hline Microdeutopus anomalus (Rathke. 1843) & Ss: 84 & Ss:359 & Ss: 86.7 & $\begin{array}{l}\text { Hs:6.7 } \\
\text { Ss:873 } \\
\end{array}$ \\
\hline Microdeutopus gryllotalpa Costa. 1853 & $\begin{array}{c}\text { Hs:940 } \\
\text { Ss:10 }\end{array}$ & Ss:20 & Ss:39.9 & $\begin{array}{c}\text { Hs: } 246.7 \\
\text { Ss: } 127\end{array}$ \\
\hline Microdeutopus obtusatus Myers. 1973 & & & Ss:3.3 & \\
\hline Microdeutopus versiculatus (Spence Bate. 1857) & Ss:580 & Ss:474 & Ss:213.3 & $\begin{array}{c}\text { Hs:6.7 } \\
\text { Ss:1823 }\end{array}$ \\
\hline Monocorophium acherusicum (Costa. 1853) & Ss:7 & $\begin{array}{c}\text { Hs: } 20 \\
\text { Ss:3 }\end{array}$ & $\begin{array}{c}\text { Hs: } 13.3 \\
\text { Ss:6.7 }\end{array}$ & \\
\hline Monocorophium insidiosum (Crawford. 1937) & Ss: 1020 & Ss:23 & Ss:90 & Hs:6.7 \\
\hline Nototropis massiliensis (Bellan-Santini. 1975) & & & Hs:6.7 & Hs:6.7 \\
\hline Perioculodes longimanus longimanus (Spence Bate \& Westwood. 1868) & Ss: 17 & & Ss: 6.6 & Ss:7 \\
\hline Phtisica marina Slabber. 1769 & Ss:676 & $\begin{array}{l}\mathrm{Hs}: 26.7 \\
\text { Ss: } 1587\end{array}$ & Ss:616.6 & $\begin{array}{l}\text { Hs:26.7 } \\
\text { Ss:1371 }\end{array}$ \\
\hline Pseudoprotella phasma (Montagu. 1804) & Ss:3 & & & \\
\hline Stenothoe bosphorana Sowinsky. 1898 & Ss:7 & & Hs:6.7 & \\
\hline Stenothoe cavimana Chevreux. 1908 & Hs: 13.3 & Hs:86.6 & Ss:3.3 & $\begin{array}{c}\text { Hs: } 20 \\
\text { Ss:3 }\end{array}$ \\
\hline Stenothoe elachista Krapp-Schickel. 1975 & & Ss:3.3 & Ss:3.3 & Hs: 80 \\
\hline Stenothoe monoculoides (Montagu. 1815) & $\begin{array}{c}\text { Hs: } 413.4 \\
\text { Ss: } 1\end{array}$ & & & Hs:2206.7 \\
\hline Stenothoe tergestina (Nebeski. 1881) & Hs:266.7 & & & \\
\hline \multicolumn{5}{|l|}{ ISOPODA } \\
\hline *Cymodoce spinosa (Risso. 1816) & & Hs:6.7 & Hs:20 & \\
\hline Dynamene bidentata (Adams. 1800) & Hs:673.4 & Hs:926.7 & Hs:20 & Hs:60 \\
\hline Dynamene bifida Torelli. 1930 & & & Hs: 6.7 & \\
\hline *Gnathia dentata (Sars G.O. 1872) & Ss:0.7 & & & \\
\hline Gnathia maxillaris (Montagu. 1804) & & Ss: 187 & & Ss:16.7 \\
\hline Gnathia vorax (Lucas. 1849) & Ss:0.6 & & & Ss:3 \\
\hline Idotea balthica (Pallas. 1772) & Hs:81753.3 & Hs:966.8 & Hs: 126.7 & Hs:4539.9 \\
\hline Idotea metallica Bosc. 1802 & Hs:226.7 & Hs:6.7 & & Hs: 1166.7 \\
\hline Jaera (Jaera) italica Kesselyak. 1938 & Hs:153.4 & & & \\
\hline Limnoria lignorum (Rathke. 1799) & & & & Ss:207 \\
\hline Paragnathia formica (Hesse. 1864) & Ss: 173 & & & \\
\hline Sphaeroma serratum (Fabricius. 1787) & Hs:940 & Hs:546.6 & Hs:26.7 & Hs:133.3 \\
\hline Stenosoma capito (Rathke. 1837) & Hs: 13.3 & Hs:20 & & \\
\hline \multicolumn{5}{|l|}{ CUMACEA } \\
\hline Iphinoe trispinosa (Goodsir. 1843) & & Ss:3 & & \\
\hline Vaunthompsonia cristata Bate. 1858 & & & Ss:3.3 & \\
\hline \multicolumn{5}{|l|}{ MYSIDA } \\
\hline Haplostylus normani (G.O. Sars. 1877) & & & Ss:3.3 & \\
\hline \multicolumn{5}{|l|}{ TANAIDACEA } \\
\hline Apseudopsis latreillii (Milne Edwards. 1828) & Ss:203.8 & $\begin{array}{l}\text { Ss: } 139 \\
\text { Hs: } 20\end{array}$ & Ss:953.3 & $\begin{array}{l}\text { Ss:67.9 } \\
\text { Hs: } 13.3\end{array}$ \\
\hline Chondrochelia savignyi (Kroyer. 1842) & Hs: 306.7 & Ss:3 & Ss:3.3 & Hs: 6.7 \\
\hline Tanais dulongii (Audouin. 1826) & $\begin{array}{c}\text { Hs:33119.8 } \\
\text { Ss:3 }\end{array}$ & Hs:2220 & Hs: 1466.6 & Hs: 2773.4 \\
\hline
\end{tabular}

*New records for Sea of Marmara

\section{Hard bottom}

A total of 46 species were obtained from hard bottom samples. Analyzing the seasonal distribution of the species, we found that the greatest number of species are obtained in spring samples, followed by summer, autumn and final winter (Fig. 3). The number of 
individuals was positively associated with temperature (r: $0.384 \mathrm{P}<0.001)$. Protohyale (Protohyale) schmidtii (Heller, 1866) is the species recording the highest number of individuals throughout the year, with an individual count of up to $178.600 \mathrm{~m}^{2}$ in the summer. Moreover, this species was a dominant and constant species across all seasons in the Strait, according to the dominance and frequency indices (Fig. 4).

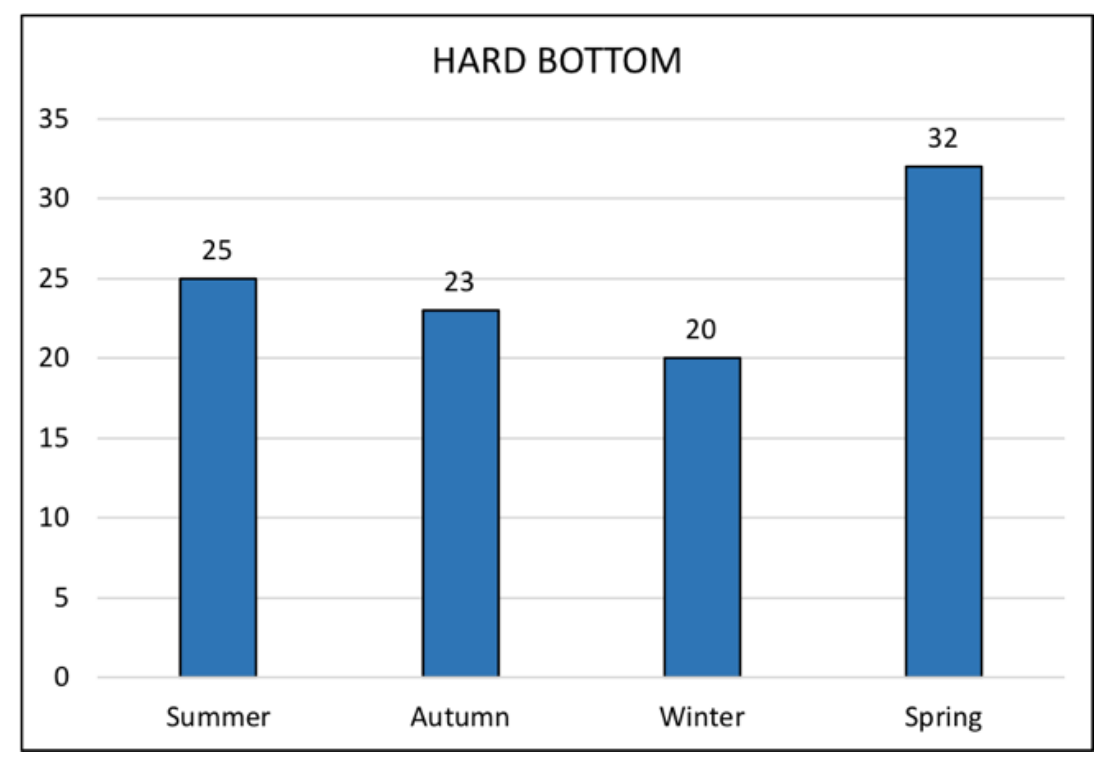

Figure 3. Seasonal changes of species numbers on the hard bottom
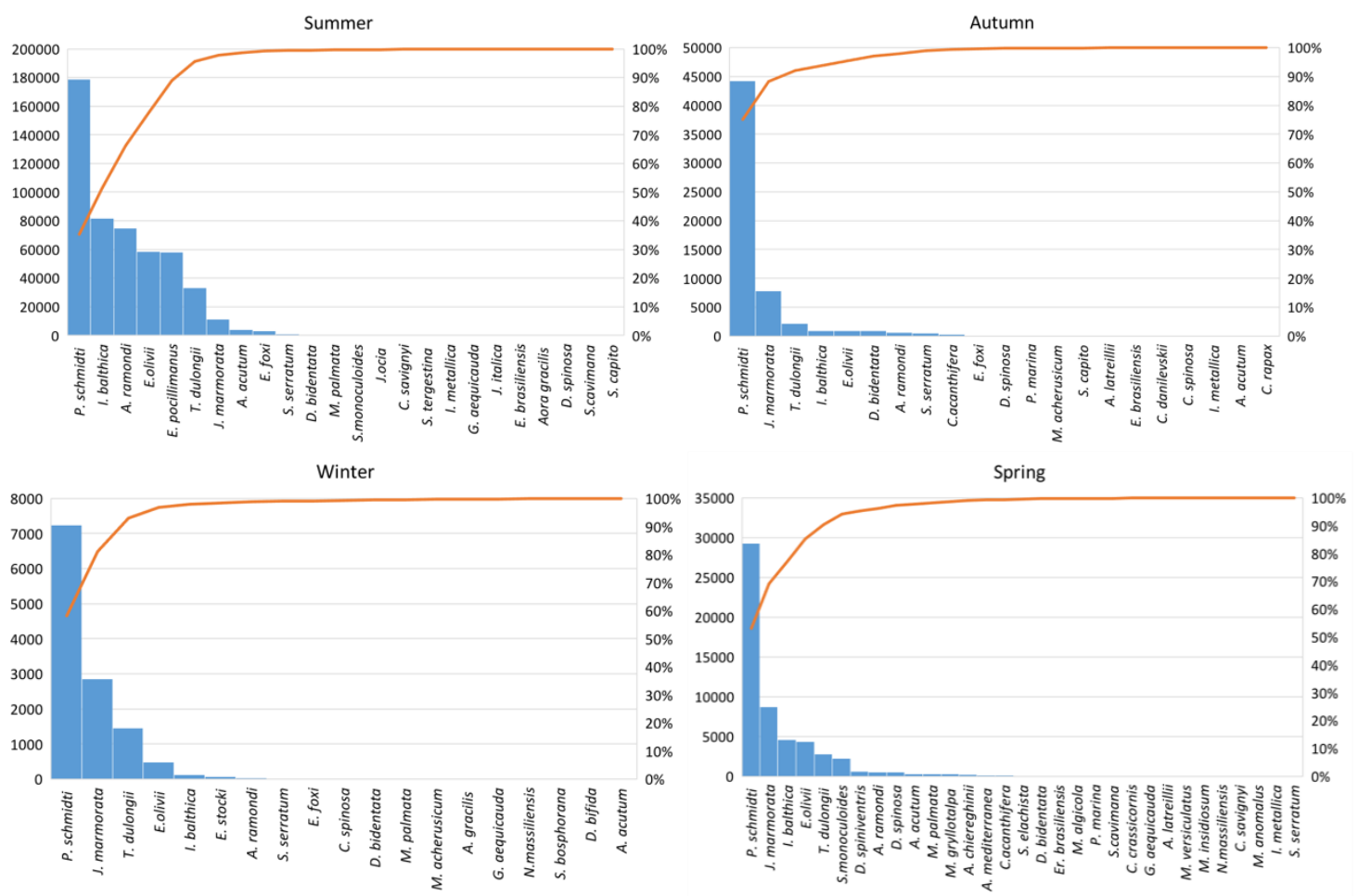

Figure 4. Seasonal variation of the Peracarid species and individual numbers at the hard bottom stations 
According to the Frequency and Dominancy Index values, most of 24 species are rare in the summer. Of the remaining species, 4 (E. pocillimanus, M. gryllotalpa, D. bidentata, and $T$. dulongii) are common and another 4 (E. olivii, P. schmidtii, J. marmorata and $I$. balthica) are constant. Of the 22 species obtained in autumn, 15 are rare, 3 (A. ramondi, E. olivii, S. serratum) are common, and 4 (P. schmidtii, J. marmorata, I. balthica, T. dulongii) are constant species. In winter, 19 species were obtained, of which 15 were found to be rare species, while 2, E. olivii and I. balthica, were common, and another 2, $P$. schmidtii and $T$. dulongii, were constant. In the spring, the last season of the study, 24 of 31 species were rare, 2 (A. acutum, A. ramondi) were common, and 5 (T. dulongii, I. balthica, P. schmidtii, E. olivii, J. marmorata) were constant species.

$H^{\prime}$ index values are determined as 0 (Autumn station 2 and winter stations 8 and 9) in stations where peracarid species were not found, while the highest $H^{\prime}$ value was 2.42 (Spring station 7) (Table 3).

Table 3. Shannon-Weaver diversity index $\left(H^{\prime}\right)$ values for hard and soft bottom stations

\begin{tabular}{|c|c|c|c|c|}
\hline \multicolumn{5}{|c|}{ HARD BOTTOM } \\
\hline Station & Summer & Autumn & Winter & Spring \\
\hline 1 & 1.44 & 0.67 & 2.1 & 0.68 \\
\hline 2 & 0.002 & 0 & 0.68 & 0.42 \\
\hline 3 & 0.72 & 0.45 & 0.93 & 0.11 \\
\hline 4 & 1.73 & 0.37 & 1.0 & 0.70 \\
\hline 5 & 1.04 & 0.60 & 0.69 & 0.75 \\
\hline 6 & 0.69 & 1.33 & 0.32 & 0.73 \\
\hline 7 & 0.28 & 0.26 & 0.54 & 2.42 \\
\hline 8 & 1.45 & 1.03 & 1.08 & 1.51 \\
\hline 9 & 0.52 & 0.003 & 0 & 1.21 \\
\hline 10 & 1.27 & 0.98 & 0 & 0.45 \\
\hline 11 & 1.35 & 0.79 & 1.02 & 1.21 \\
\hline 12 & 1.51 & 1.16 & 0.66 & 0.81 \\
\hline 13 & 1.75 & 0.8 & 0.33 & 0.65 \\
\hline \multicolumn{5}{|c|}{ SOFT BOTTOM } \\
\hline Station & Summer & Autumn & Winter & Spring \\
\hline 14 & 1.35 & 0 & 0 & 0 \\
\hline 15 & 0 & 0 & 0 & 0.69 \\
\hline 16 & 1.07 & 1.07 & 1.56 & 0 \\
\hline 17 & 1.84 & 1.38 & 1.06 & 1.51 \\
\hline 18 & 0 & 1.1 & 2.17 & 0.58 \\
\hline 19 & 1.01 & 0 & 0 & 0.59 \\
\hline 20 & 1.27 & 2.13 & 1.31 & 1.6 \\
\hline 21 & 2.07 & 0 & 0 & 0 \\
\hline 22 & 2.58 & 2.11 & 0 & 2.45 \\
\hline 23 & 2.55 & 0 & 0 & 0 \\
\hline 24 & 2.74 & 1.80 & 2.03 & 0.87 \\
\hline 25 & 0 & 0.97 & 2.08 & 2.18 \\
\hline 26 & 0 & 1.34 & 2.39 & 1.98 \\
\hline 27 & 0 & 0 & 0 & 0.69 \\
\hline 28 & 0 & 0 & 1.46 & 1.25 \\
\hline 29 & 0 & 0 & 0 & 0.87 \\
\hline 30 & 0.66 & 0 & 1.54 & 0.53 \\
\hline 31 & 0 & 0 & 1.6 & 0.84 \\
\hline 32 & 0 & 0 & 0 & 0 \\
\hline 33 & 0 & 0 & 0 & 0 \\
\hline 34 & 0 & 0 & 0 & 0 \\
\hline
\end{tabular}


As for similarities between stations, the station groups showing the highest similarity in summer were S4, S7, and S12, as well as S5 and S9 (Fig. 5). R values calculated using ANOSIM (similarity analysis) in the hard substratum and we found significant values. $R$ values respectively for summer $(R=0.638, P<0.01)$; autumn $(R=0.797$, $\mathrm{P}<0.01)$; winter $(\mathrm{R}=0.917, \mathrm{P}<0.01)$; spring $(\mathrm{R}=0.813, \mathrm{P}<0.01)$. The species $P$. schmidtii, E. olivii and I. balthica contributed greatly to the similarity of the first group, while P. schmidtii, T. dulongii and I. balthica contributed most to that of the of the second. Similarity percentages increased between stations in autumn, when the most similar group consisted of stations A6 and A12, the second most similar was A3, A4, and A5, and the third was A1, A8, and A9. P. schmidtii, J. marmorata and T. dulongii contributed most to this similarity. The highest similarity in winter was between stations W2, W4, W5, W1, and W12. The second most similar group was W3 and W7. Similar to other seasons, the resemblance was heavily influenced by P. schmidtii, T. dulongii, J. marmorata and I. balthica. The highest similarity in spring was between stations SP11, SP12, and SP13, followed by a group consisting of stations SP2, SP3, SP4, and SP5. Unlike other seasons, $H$. normani, J. italica, S. tergestina and E. foxi contributed most to the similarity in spring $P$. schmidtii was the species that contributed most to similarities across all seasons, except in spring at hard bottom stations.
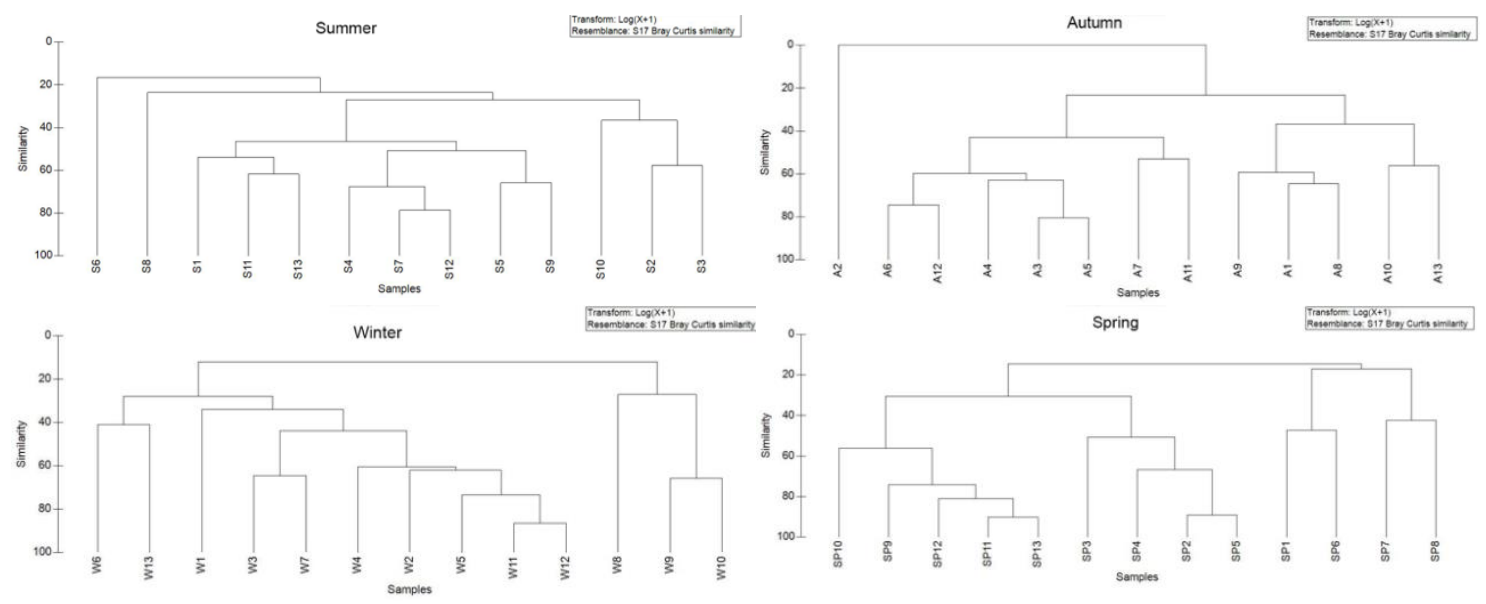

Figure 5. The similarity of the hard bottom stations. S: Summer A: Autumn W: Winter SP: Spring

\section{Soft bottom}

Sixty peracarid species were obtained in soft bottom sampling. Most species (38) were obtained in the summer, followed by spring (27). The number of species obtained in autumn (23) and winter (24) was nearly equal (Fig. 6). In analyzing frequency and dominancy index values for species in soft bottom samples, we see that the only common species is A. acutum, and only in spring. In all other seasons, all species were rarely obtained (Fig. 7). 


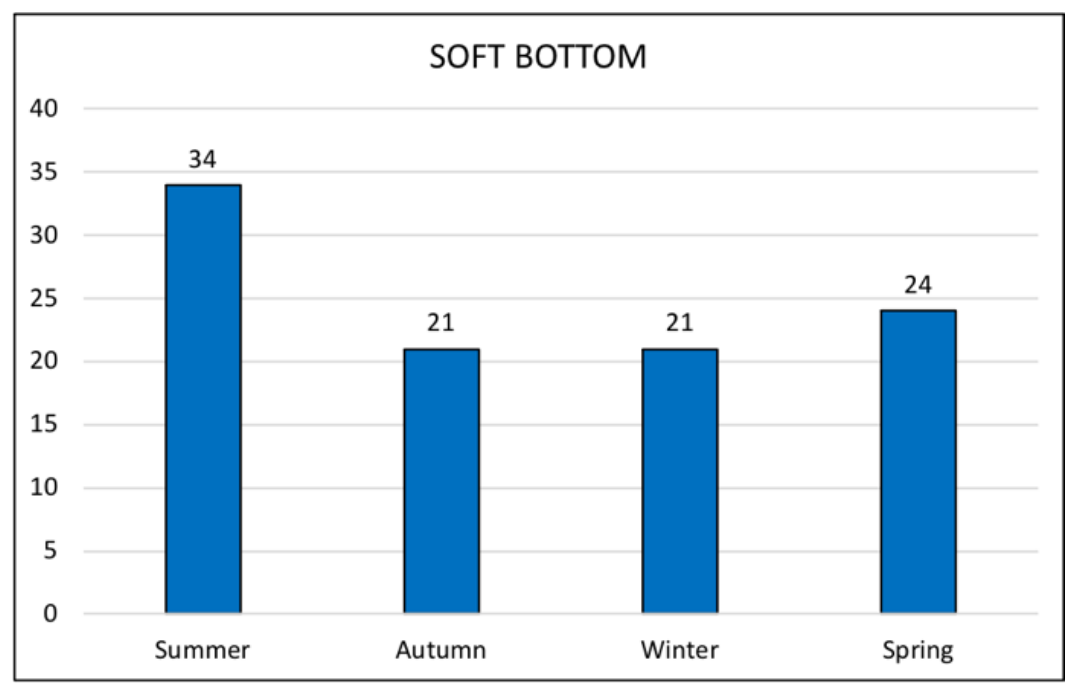

Figure 6. Seasonal changes of species numbers on the soft bottom
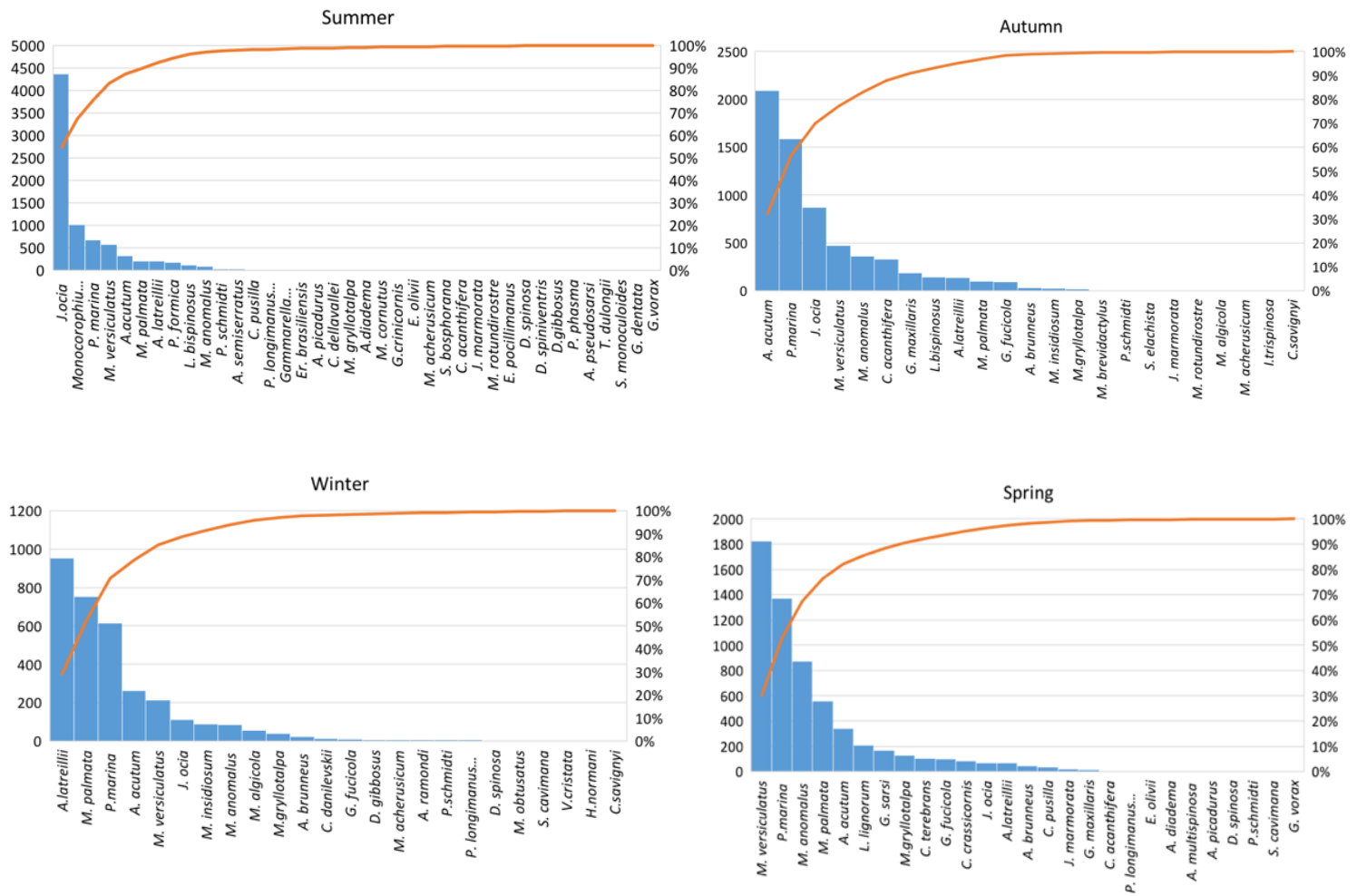

Figure 7. Seasonal variation of the Peracarid species and individual numbers at the soft bottom stations

$H^{\prime}$ index values range from 0 to 2.7. Peracarids could not be obtained throughout the year at some stations $(32,33$ and 34$)$ and the $H^{\prime}$ value of these stations is zero. The highest $H^{\prime}$ values were found at $24^{\text {th }}$ (Salacak) and $23^{\text {rd }}$ (Karaköy) stations ( $H^{\prime}=2.7$ and $H^{\prime}=2.5$ ) in the summer (Table 3). 
Similarity values between soft bottom stations were lower than between hard bottom stations (Fig. 8). For the soft bottom, there was a significant difference between the groups formed in all seasons (summer $(\mathrm{R}=0.791, \mathrm{P}<0.01)$; autumn $(\mathrm{R}=0.960$, $\mathrm{P}<0.01)$; winter $(\mathrm{R}=0.778, \mathrm{P}<0.01)$; spring $(\mathrm{R}=0.958, \mathrm{P}<0.01)$. The highest similarity in summer in stations with soft bottom sampling is between S14 and S16. This resemblance was caused by $P$. schmidtii and A. acutum. The stations A20 and A24, as well as a group of A16, A17, and A25 showed similarity in autumn. While L. bispinosus, $M$. versiculatus and $G$. fucicola greatly contributed to the similarity of the first group, $M$. palmata and $P$. marina contributed to the similarity of the second group. In winter, stations W16 and W17, and stations W24 and W25 were similar groups. P. marina, $M$. gryllotalpa and $M$. palmata contributed to the similarity of the first group and $P$. marina, A. acutum, L. pilosus and $M$. algicola contributed to the similarity of the second group. In the spring, stations SP14, SP19, 27 and stations SP24 and SP29 were similar. The species that most contributed to the first group were A. acutum and P. marina, while $M$. versiculatus and $M$. palmata contributed to the second group.
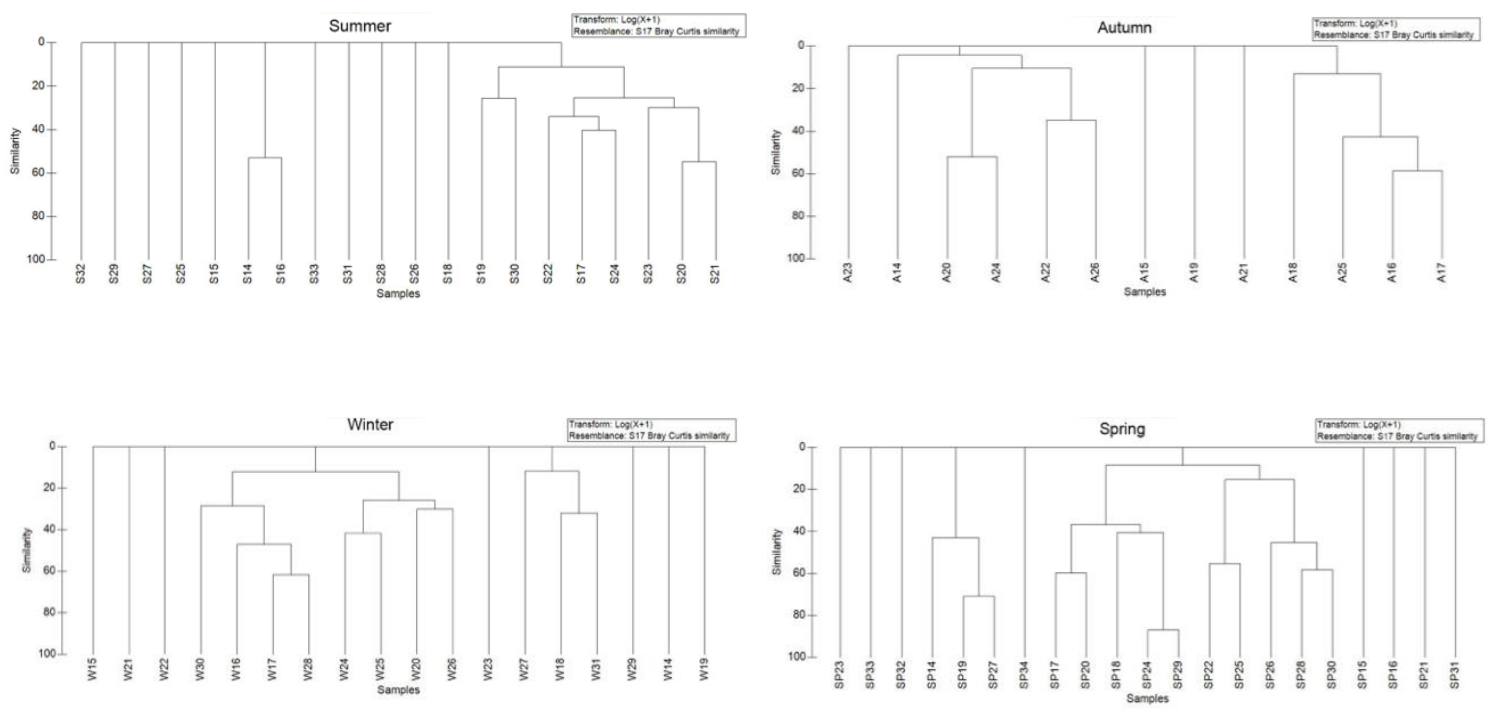

Figure 8. The similarity of the soft bottom stations. S: Summer A: Autumn W: Winter SP: Spring

\section{Physicochemical parameters}

At hard bottom stations, sea water temperature ranged from $7.17{ }^{\circ} \mathrm{C}$ (winter) to $24.6{ }^{\circ} \mathrm{C}$ (summer), dissolved oxygen from 7.64 (autumn) to $15.08 \mathrm{mg} \mathrm{l}^{-1}$ (winter), dissolved oxygen percentage from $89.5 \%$ (autumn) to $156.6 \%$ (summer) and salinity content ranged from 14.10 (winter) to 24.43 PSU (practical salinity unit) (winter) (Fig. 9).

We conducted Spearman's correlation analysis to elucidate the relationships between parameters. Accordingly, we found a negative relationship ( $\mathrm{r}:-0.702 \mathrm{P}<0.001$ ) between temperature and dissolved oxygen. In contrast, there was a positive $(\mathrm{r}: 0.605 \mathrm{P}<0.001)$ relationship between species number and temperature. A negative $(\mathrm{r}:-0.365 \mathrm{P}<0.001)$ relationship was observed between species number and both dissolved oxygen and number of individuals. The number of individuals was positively associated with temperature ( $\mathrm{r}: 0.384 \mathrm{P}<0.001$ ), and negatively with dissolved oxygen ( $\mathrm{r}:-0.346$ $\mathrm{P}<0.001)$. 

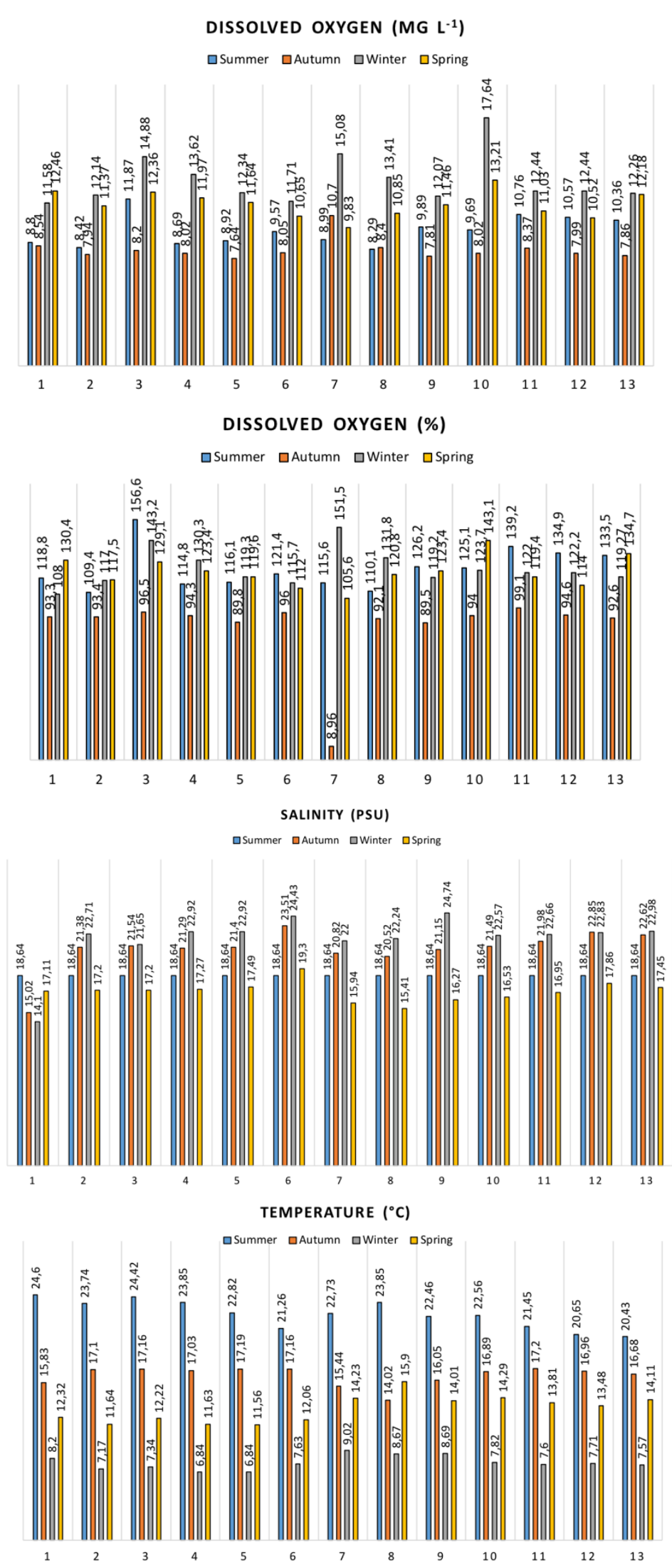

Figure 9. Physicochemical parameters of the seawater of the hard bottom $(0.5 \mathrm{~m})$ stations. DO: dissolved oxygen $\left(m g l^{-1}\right)$ DO: dissolved oxygen (\%) S: salinity (PSU) T: temperature $\left({ }^{\circ} \mathrm{C}\right)$ 
In soft bottom stations, seawater temperature values were between $6.55{ }^{\circ} \mathrm{C}$ (winter) and $23.5{ }^{\circ} \mathrm{C}$ (summer), dissolved oxygen values were between 1.84 (autumn) and $17.98 \mathrm{mg} \mathrm{l}^{-1}$ (winter), dissolved oxygen percentage values were between $7.95 \%$ (summer) and $139 \%$ (summer) and salinity values were between 16.2 (spring) and 46.44 (autumn) PSU (practical salinity unit). The lowest measured oxygen values were obtained at stations 21 (Ortaköy) and 23 (Karaköy) at $36.4 \mathrm{~m}$ depth for all seasons. High oxygen values were obtained at station 15 (Garipçe) (Figs. 10 and 11). We also found a negative relationship between dissolved oxygen values and depth as expected. (r: -0.297 $\mathrm{P}<0.001$ ). Salinity increased as expected due to the Mediterranean water below ( $\mathrm{r}: 0.439$ $\mathrm{P}<0.001)$.
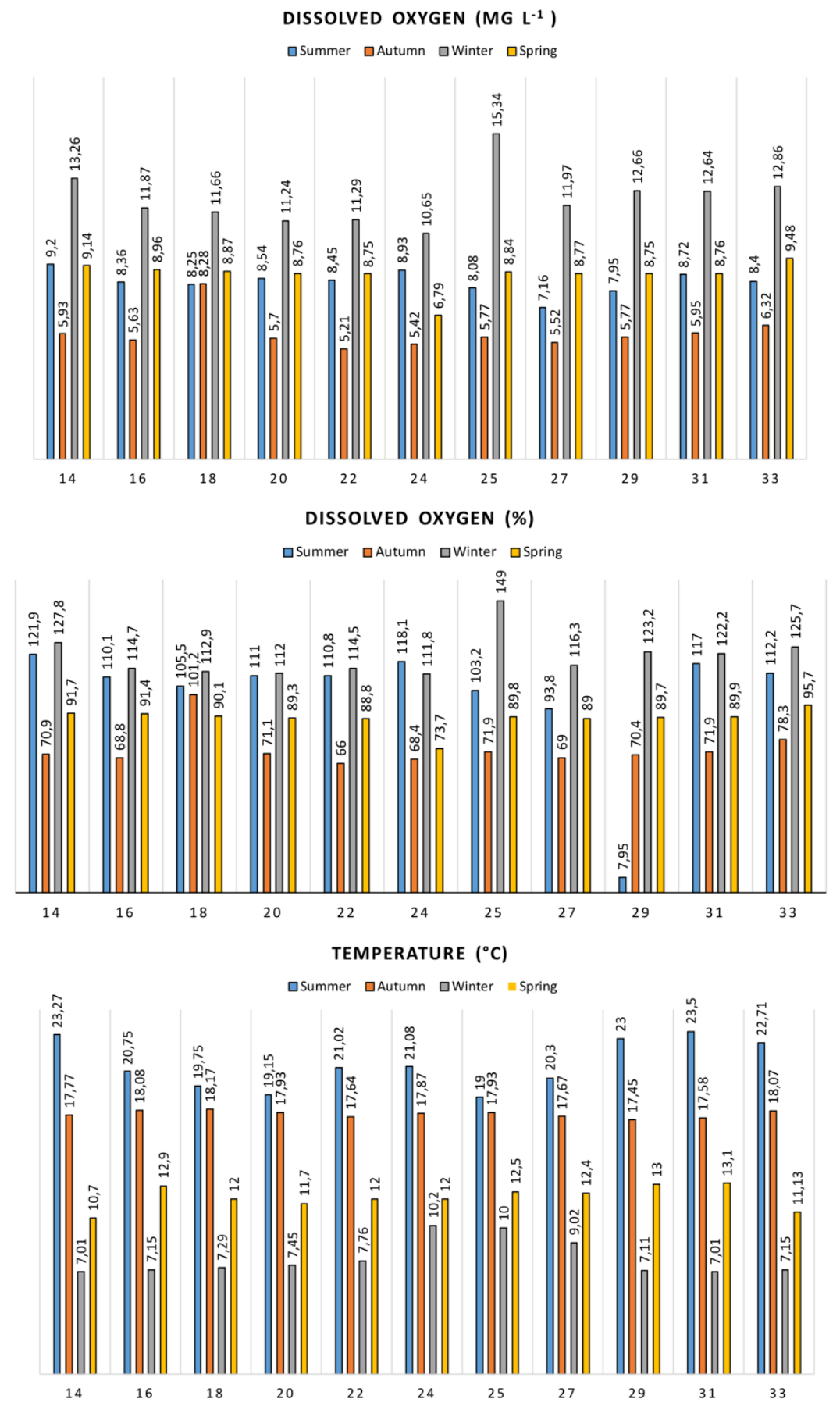


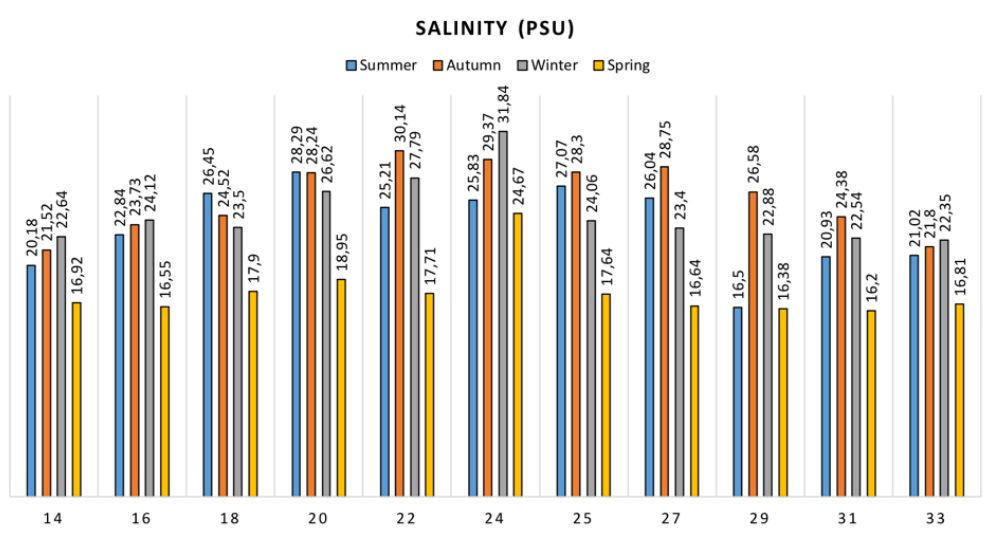

Figure 10. Physicochemical parameters of the seawater of the soft bottom $(18.2 \mathrm{~m})$ stations DO: Dissolved Oxygen $\left(m g l^{-1}\right)$ DO: Dissolved Oxygen (\%). T: Temperature $\left({ }^{\circ} \mathrm{C}\right) \mathrm{S}$ : Salinity $(\mathrm{PSU})$

The lowest Total Organic Carbon (TOC) value (0.2\%) was found at stations 14 (Garipçe), 27 (Anadoluhisarı) and 31 (Anadolukavağı), while the highest values were obtained at station 23 (Karaköy) (6.4 and 5.2\%). Total inorganic carbon values were between 3.09\% (Çengelköy, station 25) and 56.22\% (Paşabahçe, station 30) (Table 4). We identified statistically significant but a weak negative relationship between TOC values and DO (r: - 0.186 P < 0.001). A positive relationship was observed between TOC and both salinity values ( $\mathrm{r}: 0.324 \mathrm{P}<0.001)$ and mud percentage $(\mathrm{r}: 0.360 \mathrm{P}<0.001)$. The relationship between TIC and mud percentage was negative ( $\mathrm{r}:-0.244 \mathrm{P}<0.001)$.

In this study, no statistically significant relationship was found between TOC and TIC values.

Table 4. Physicochemical parameters determined in the soft bottom surface sediment samples of Istanbul Strait

\begin{tabular}{|c|c|c|c|c|c|c|c|c|c|}
\hline \multicolumn{5}{|c|}{ TOC $(\%)$} & \multicolumn{4}{|c|}{ TIC (\%) } & \multirow{2}{*}{$\begin{array}{c}\text { MUD } \\
\text { PERCENTAGE }(\%)\end{array}$} \\
\hline STATION & SUMMER & AUTUMN & WINTER & SPRING & SUMMER & AUTUMN & WINTER & SPRING & \\
\hline 14 & 0.36 & 0.62 & 0.84 & 0.21 & 13.90 & 13.90 & 10.81 & 8.3 & 9.50 \\
\hline 15 & 2.02 & 0.71 & 0.39 & 2.57 & 32.43 & 7.72 & 30.89 & 32.43 & 16.00 \\
\hline 16 & 2 & 1.05 & 1.05 & 0.47 & 6.18 & 4.63 & 20.08 & 21.62 & 24.97 \\
\hline 17 & 0.82 & 0.75 & 1.51 & 0.23 & 26.25 & 24.5 & 18.53 & 20.08 & 29.03 \\
\hline 18 & 0.92 & 0.31 & 0.85 & 0.99 & 21.62 & 17 & 13.90 & 10.81 & 6.47 \\
\hline 19 & 0.51 & 0.28 & 0.38 & 0.31 & 9.27 & 4.63 & 15.74 & 16.99 & 5.28 \\
\hline 20 & 2.68 & 1.11 & 3.24 & 2.5 & 10.81 & 3.09 & 7.72 & 10.81 & 41.94 \\
\hline 21 & 2.18 & 4.12 & 1.39 & 2.2 & 9.27 & 10.81 & 7.72 & 10.81 & 20.41 \\
\hline 22 & 1.63 & 0.58 & 2.5 & 2.7 & 6.18 & 26.25 & 7.72 & 7.1 & 69.9 \\
\hline 23 & 2.3 & 2.48 & 6.4 & 5.2 & 6.18 & 6.18 & 7.1 & 7.7 & 72.66 \\
\hline 24 & 1.05 & 0.56 & 0.65 & 0.83 & 37.07 & 13.90 & 33.98 & 30.89 & 10.86 \\
\hline 25 & 2.9 & 1.1 & 2.09 & 1.44 & 3.09 & 24.71 & 15.44 & 25.64 & 17.56 \\
\hline 26 & 0.9 & 1.1 & 0.63 & 0.9 & 4.63 & 9.27 & 24.71 & 24.69 & 25.99 \\
\hline 27 & 0.95 & 0.2 & 0.74 & 0.2 & 3.09 & 4.60 & 4.63 & 3.09 & 1.44 \\
\hline 28 & 0.62 & 0.84 & 0.61 & 0.2 & 4.63 & 4.63 & 4.63 & 4.63 & 21.26 \\
\hline 29 & 0.75 & 0.78 & 0.66 & 0.8 & 13.90 & 12.35 & 10.81 & 13.90 & 25.47 \\
\hline 30 & 0.8 & 1.78 & 1 & 1.2 & 12.35 & 44.79 & 15.44 & 56.22 & 13.48 \\
\hline 31 & 2.04 & 0.51 & 0.2 & 0.69 & 12.35 & 9.27 & 16.98 & 24.69 & 18.23 \\
\hline 32 & 0.6 & 0.57 & 0.64 & 0.95 & 7.72 & 8.3 & 4.63 & 6.18 & 84.57 \\
\hline 33 & 1.23 & 1.02 & 1.11 & 1.55 & 7.72 & 24.71 & 15.44 & 6.18 & 2.52 \\
\hline 34 & 3.47 & 3.15 & 2.51 & 0.69 & 6.18 & 18.53 & 38.61 & 24.69 & 16.61 \\
\hline
\end{tabular}

TOC: total organic carbon, TIC: total inorganic carbon 

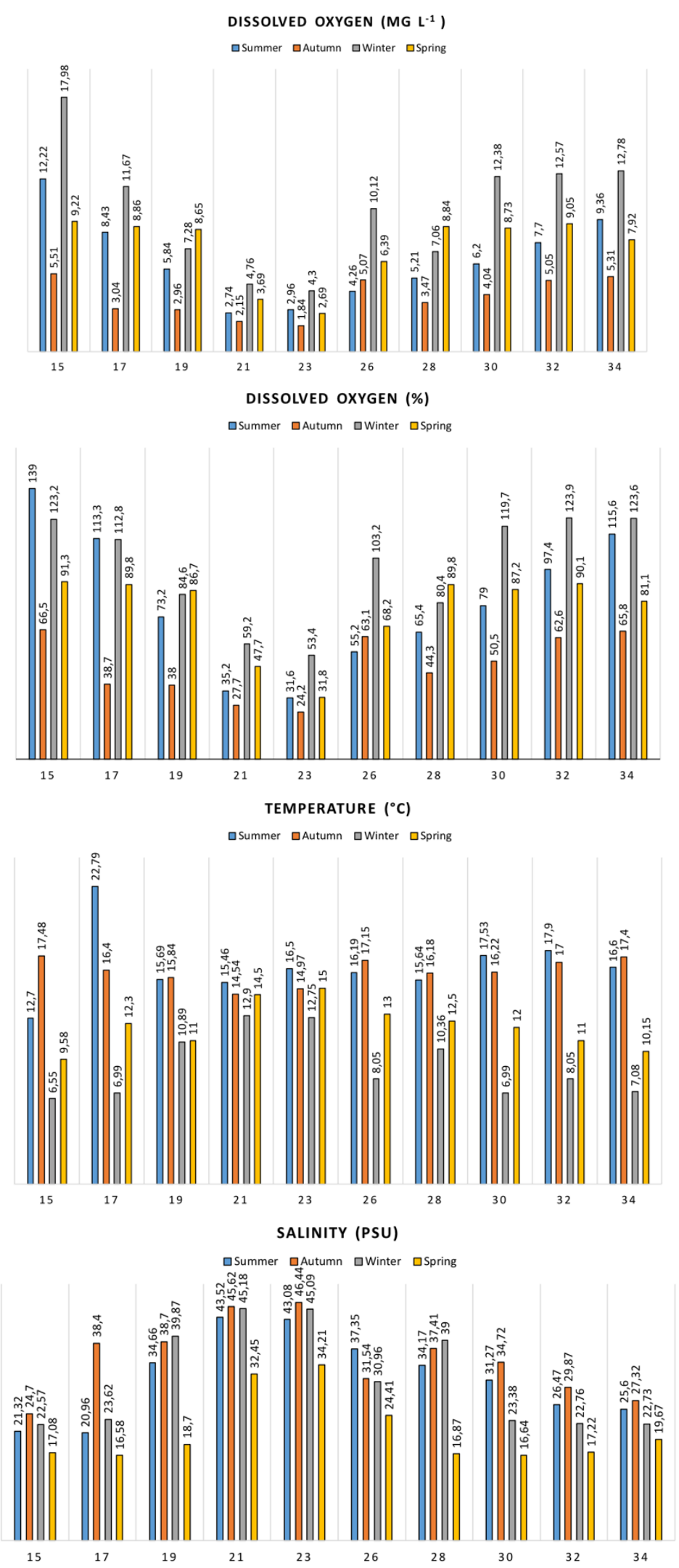

Figure 11. Physicochemical parameters of the seawater of the soft bottom $(36.4 \mathrm{~m})$ stations. DO: Dissolved Oxygen $\left(\mathrm{mg} \mathrm{l}^{-1}\right)$ DO: Dissolved Oxygen (\%) T: Temperature $\left({ }^{\circ} \mathrm{C}\right) \mathrm{S}$ :Salinity $(P S U)$ 


\section{Discussion}

In this study, we found 46 species in hard bottom and 58 in soft bottom stations. Coastal filling to create artificial areas for ports, parks, and recreation areas is common on the shores of the Istanbul Strait. It has been observed that natural areas are in decline as artificial areas gradually increase in the Istanbul Strait (Onuk et al., 2017). For this reason, we experienced difficulty in finding natural stations to sample. The limited number of hard bottom stations to be found were surrounded by restaurants, residential areas, and anchored boats. Hard bottom macrobenthos is heavily influenced by habitat type and the hydrodynamic processes are particularly effective in the distribution of macrobenthic fauna, especially in the Istanbul Strait (Uysal et al., 2002). Water movements directly affect benthic organisms living in the sediment on the soft bottom, causing the transport of sediment and organic matter. In addition, hydrodynamic conditions change the distribution of the macrobenthic community in that region by changing the grain size distribution (Foulquier et al., 2020). Uysal (2002) states in his study in the Istanbul Strait that only one of the stations in the lower layer current system consists of fine sand and silt-containing mud. This station is located at the Black Sea exit of the Istanbul Strait. Researcher says that the sediments of other stations contain coarsegrained shells due to their high flow rates.

During the study, we observed that the number of species increased seasonally with temperature, and most species were collected in spring. Peracarid biodiversity depends on many factors, such as vegetation, hydrodynamics, sedimentation carbonates, habitats, and combinations of all of these features, and it has been observed in previous studies that biodiversity increases especially in spring (Wang et al., 2010). In addition to the increase in algae and mussels, which form the hard bottom communities and hosts of peracarids, this increase can also be influenced by the rising reproduction rates in the spring months when the temperature is high. According to Izquierdo and Garcia et al. (2011), peracarids reproduce year-round in the Strait of Gibraltar, but they are most abundant in spring and summer. The researchers linked this situation to seasonal changes in sea meadows, but factors such as predation and competition should also be evaluated (Izquierdo and Garcia, 2011).

The primary reason for the lack of species from the Mysid and Cumacea orders is that these peracarids prefer soft bottom habitats. However, it may also be related to the flow system and quadrat sampling on the shore (Wang et al., 2010). In this study, sampling was performed with a quadrat on hard bottom, but some researchers use a hand scoop or plankton nets to collect mysids (Porter, 2016).

The dominance of the amphipod species $P$. schmidtii in hard bottom stations is remarkable. Ampithoe ramondi, Protohyale (Protohyale) schmidtii and Elasmopus brasiliensis species were found to be dominant in a rocky community study in Gökçeada (Aslan and İşmen, 2019). Species with high frequency and dominance in this study, such as Hyale and Jassa, are tolerant of pollution (Kalkan et al., 2007). In this study, Tanais, which was obtained predominantly on the shores of the Istanbul Strait, was widely obtained from clean waters and harbors by various researchers. (Chintiroglou et al., 2004). In a previous study in the Istanbul Strait, Hyale perieri, E. olivii, J. marmorata and T. dulongii were dominant in discharge areas (Kalkan et al., 2007). Similarly, in this study, these species show high dominance the Istanbul Strait coast, including Beşiktaş, Sariyer, and Tarabya, where the settlement was intense.

In this study, Cumacea, Mysid, and Tanaid species were represented by many fewer species than other orders. Cumacea and Mysid species (I. trispinosa, V. cristata, $H$. 
normani) obtained were distributed on only soft bottom stations. Only 3 tanaid obtained (A. latreillei, C. savignyi and T. dulongi). We obtained these tanaid species on both soft and hard bottom. However, A. latreillei has a high number of individuals on soft bottom and T. dulongi on hard bottom. Amphipods (195 species) make up the most 418 Malacostracan species in the Turkish Straits System. This is followed by decapoda (140), Isopoda (42), Cumacea (18), Mysidacea (12), Tanaidacea (7), Stomatopoda (2) and Leptostraca (1), respectively (Balk1s et al. 2016). In the studies performed in the Sea of Marmara and the Black Sea, it is seen that the Amphipods are dominant in the crustacean fauna (Sezgin et al. 2010; Bat et al., 2011; Bakır et al., 2012). This study reports the first record of the Atlanto-Mediterranean maerid amphipod Animoceradocus semiserratus in Sea of Marmara. This species is distributed throughout the Atlantic Ocean and Mediterranean Sea (Christodoulou et al., 2013). The existence of this species in Turkish seas was unknown until recently (Mutlu, 2020). However, considering the sampling date of the researcher, it is seen that it has been in our waters for a long time. Previous records of the species are from the Aegean and the Mediterranean Sea, and it is observed that Mediterranean origin species increase in the Sea of Marmara.

In sampling on soft bottom, stations were selected from two depths $(18.2 \mathrm{~m}$ and $36.4 \mathrm{~m}$ ) with a difference in salinity between them. However, according to the Spearman analysis, no significant relationship was found between depth differentiation and the number of species and individuals. While salinity is an important factor in lagoons, sediment type and amount of organic matter are more critical in the distribution of peracarids in marine ecosystems (Lourido et al., 2008; Zaabar et al., 2017). The strait's sediment has a coarse-grained structure (Uysal et al., 2002). In this study, the mud percentage values in the sampled soft bottom stations vary between $1.44 \%$ and $84.57 \%$ with an average value of $25.4 \%$. Only a few stations had high mud percentages. A weak but positive correlation was found between the number of species and individuals and the mud percentage $(\mathrm{r}: 0.221 \mathrm{P}<0.001)$. The same relationship was also observed between the mud percentage and organic carbon. This can be explained by the fact that the amount of organic matter increases as the mud percentage increases. Fine grain sediments do not permit the entry of oxygen, increasing the absorption of organic matter. (Secrieru and Oaie, 2009). This organic material is an important parameter, especially for detritivore species, as it constitutes a food source. Two of the two stations which lack peracarids throughout the year (33 and 34) are located in Keçilik, which has vortex (Atasoy, 2008). The associated strong current is one reason why species were not collected in these stations. In the spring, high $H^{\prime}$ index values were obtained in the Ortaköy (Station 20), Karaköy (station 22), and Salacak (station 25) areas, which have low dissolved oxygen values and were observed to be discharge regions during sampling. This is due to the density of the species, which feed on detritus at these stations. The high organic carbon content, especially at Karaköy and Ortaköy stations supports this idea and indicates the organic contamination at these points. The strait's sediment samples show high organic carbon content values, especially in the summer. Anthropogenic organic pollution was remarkable at station 34 Keçilik (3.47\%), station 20 Ortaköy (2.68\%), and station 23 Karaköy (2.3\%) stations, where the highest percentage of carbon was obtained. Low dissolved oxygen content in the same areas confirms this result. Again, the lowest dissolved oxygen values in seawater were measured at $36.4 \mathrm{~m}$ depths in Karaköy and Ortaköy in all seasons, and this is one of the results of oxygen deficiency in the bottom layers and organic pollution in the strait. 


\section{Conclusion}

As a result, with this study, we examined the Istanbul Strait peracarid fauna in detail in both hard and soft bottoms and reported species that were not observed in the Bosphorus and Sea of Marmara before. Thus, we ensured the update of macrozoobenthic fauna information. We have observed that most of the species we have obtained are of Atlanto-mediterranean origin, and a few species are Mediterranean endemic or cosmopolitan species. Considering that the Istanbul Strait creates a natural transition between the Mediterranean and the Black Sea, it is an expected result to obtain the species previously identified from the Mediterranean from the Istanbul Strait. We have observed that in the distribution of species in the strait, ground structure, temperature, organic carbon amount and current system are more effective than the salinity difference of Black Sea and Mediterranean waters. We think that the analysis of grain size in future studies will be useful for understanding the habitat structure and distribution. We stated that we had difficulty in finding natural coastal areas during the hard bottom sampling of the study. We think that the coastal filling creates negativity for distributing of macrozoobenthic organisms in the strait. The decrease in the amount of oxygen with depth and high carbon amount in certain areas can be considered as a warning for the pollution in the strait. However, since this study is not a pollution study, it was conducted to determine the diversity and distribution of peracarids, we recommend increasing pollution studies in the region. Moreover, this study cannot comment on the overall benthic ecological quality of the strait, since only peracarid species were examined. For this reason, the authors recommend following it up with studies on ecological quality in the future.

Acknowledgments. The author is grateful to Dr. Senem Çağlar, Ph.D., Mert Kesiktaş, Msc. Elif Yücedağ, Dr. Güley Kurt, and Ph.D., Begüm Ayfer. This study was supported by the Research Fund of Istanbul University (project number BAP 53379).

\section{REFERENCES}

[1] Aslan-Cihangir, H., Pancucci-Papadopoulou, M. A. (2011): Spatial and temporal variation of soft-bottom peracarid (Crustacea: Peracarida) infauna in the Çanakkale Strait (Turkey). - Mediterranean Marine Science 12(1): 153-182. DOI: 10.12681/mms.58.

[2] Aslan, H., İşmen, P. (2019): Peracarid crusteceans species from upper infralittoral rocky shores of Gokceada Island (Aegean Sea). - Çanakkale Onsekiz Mart University Journal of Marine Sciences and Fisheries 2(1): 109-119.

[3] Atasoy, C. (2008): Investigation of local traffic in Istanbul Strait. - Master Thesis, Istanbul Technical University, Istanbul, Turkey.

[4] Băcescu, M. (1982): Contributions à la connaissance des cumacés de la mer de Marmara et d'Égée (Ile Eubea). - Travaux du Muséum d'Histoire Naturelle Grigore Antipa 497(24): 45-54.

[5] Bakır, K. (2012): Contributions to the knowledge of crustaceans on soft bottoms in the Sea of Marmara, with a checklist. - Crustaceana 85(2): 219-236. DOI: $10.1163 / 156854012 X 626437$.

[6] Bakır, K., Sezgin, M., Katağan, T. (2016): The amphipods (Arthropoda: Crustacea) in the Turkish straits with new records. - Cahiers De Biologie Marine 57: 403-414. DOI: 1021411/CBMAAF27654E.

[7] Balkıs, N., Albayrak, S., Balkıs, H. (2002): Check-list of the Crustacea fauna of the Bosphorus. - Turkish Journal of Marine Sciences 8: 157-164. 
[8] Balkis, H., Mülayim, A., Karhan, S. (2016): Crustacea Malacostraca in the Sea of Marmara: A Checklist the Sea of Marmara. - In Özsoy, E., Çağatay, M. N., Balkıs, N., Balkıs, N., Öztürk, B. (eds.) Marine Biodiversity, Fisheries, Conservation and Governance. Turkish Marine Research Foundation (TUDAV), Publication No: 42, Istanbul, Turkey.

[9] Bat, L., Sezgin, M., Satılmış, H. H., Şahin, F., Üstün, F., Birinci Özdemir et al. (2011): Biological diversity of the Turkish Black Sea Coast. - Turkish Journal of Fisheries and Aquatic Sciences 11: 683-692. DOI: 10.4194/1303-2712-v11_4_04.

[10] Bellan-Santini, D. (1969): Etude floristuque et faunistuque de quelques peuplements infralittoraux de substrat rocheux - Travaux de la Station Marine d'Endoume 26: 237-298.

[11] Beşiktepe, Ş. T., Sur, H. İ., Özsoy, E., Abdullatif, M. A., Oğuz, T et al. (1995): The circulation and hydrography of the Marmara Sea. - Progress in Oceanography 34: 285-334.

[12] Birpınar, M. E., Talu, G. F., Gönençgil, B. (2009): Environmental effects of maritime traffic on the İstanbul Strait. - Environmental Monitoring and Assessment 152: 13-23. DOI: 10.1007/s10661-008-0292-8.

[13] Caspers, H. (1968): La macrofauna benthique du Bosphore et les problèmes de I'infiltration des éléments Méditerranéens dans la mer Noire - Rapport du Congrès de la Commission Internationale pour l'Exploration Scientifique de la Mer Méditerranée 19: 107-115.

[14] Chintiroglou, C. C., Antoniadou, C., Baxevanis, A., Damianidis, P., Karalis, P et al. (2004): Peracarida populations of hard substrate assemblages in ports of the NW Aegean Sea (Eastern Mediterranean). - Helgoland Marine Research 58(1): 54-61. DOI: 10.1007/s10152-003-0168-9.

[15] Christodoulou, M., Paraskevopoulou, S., Syranidou, E., Koukouras, A. (2013): The amphipod (Crustacea: Peracarida) fauna of the Aegean Sea, and comparison with those of the neighbouring seas. - Journal of the Marine Biological Association of the United Kingdom 93(5): 1303-1327. DOI: 101017/S002531541200183X.

[16] Clarke, K. R., Warwick, R. M. (2001): Change in Marine Communities: An Approach to Statistical Analysis and Interpretation. 2nd Ed. - PRIMER-E, Plymouth.

[17] Dauvin, J. C., Ruellet, T. (2007): Polychaete/amphipod ratio revisited. - Marine Pollution Bulletin 55: 215-224. DOI: 10.1016/j.marpolbul.2006.08.045.

[18] Demir, M. (1952): Benthic invertebrates of the Bosporus and Prince Islands. - Publications of Istanbul University, Faculty of Science, Department of Hydrobiology 3: 1-615.

[19] Foulquier, C., Baills, J., Arraud, A., D’Amico, F., Blanchet, H et al. (2020): Hydrodynamic conditions effects on soft-bottom subtidal nearshore benthic community structure and distribution. - Hindawi Journal of Marine Sciences 2020: 1-16.DOI: $10.1155 / 2020 / 4674580$.

[20] Galehouse, J. S. (1971): Sedimentation Analysis. - In: Carver, R. E. (ed.) Procedures in Sedimentary Petrology. Wiley, New York.

[21] Gaudette, H., Flight, W., Tanner, L., Folger, D. (1974): An expensive titration method for the determination of organic carbon in recent sediments. - Journal of Sedimentary Petrology 44: 249-253.

[22] Guerra-García, J. M., Ros, M., Sánchez, J. A. (2009): Isopods, tanaids and cumaceans (Crustacea, Peracarida) associated to the seaweed Stypocaulon scoparium in the Iberian Peninsula. - Zoologica Baetica 20: 35-48.

[23] Izquierdo, D., Guerra-García, J. M. (2011): Distribution patterns of the peracarid crustaceans associated with the alga along the intertidal rocky shores of the Iberian Peninsula. - Helgoland Marine Research 65(2): 233-243. DOI: 101007/s10152-010-0219y.

[24] Kalkan, E., Karhan, S. Ü., Mutlu, E. (2006): Preliminary investigations on crustaceans associated with the Mediterranean mussel (Mytilus galloprovincialis Lamarck, 1819) beds in the upper infralittoral of the Bosphorus (Turkey). - Annales, Seria Historia Naturalis 16: $5-8$. 
[25] Kalkan, E., Karhan, S.Ü., Mutlu, E., Simboura, N., Bekbölet, M. (2007): Application of the bentix index in assessing ecological quality of hard substrata: a case study from the Bosphorus Strait, Turkey. - Mediterranean Marine Science 8(1): 15-29.

[26] Loring, D. H., Rantala, R. T. T. (1992): Manuel for the geochemical analyses of marine sediments and suspended particulate matter. - Earth Science Reviews 32: 235-283.

[27] Lourido, A., Cacabelos, E., Troncoso, J. S. (2008): Patterns of distribution of the polychaete fauna in subtidal soft bottoms of the Ría de Aldán (North-Western Spain). - Journal of the Marine Biological Association of the United Kingdom 88: 263-275. DOI: $10.1017 /$ S0025315408000696.

[28] Mac Manus, J. (1991): Grain Size Determination and Interpretation. - In: Tucker, M. E. (ed.) Techniques in Sedimentology. Blackwell, Oxford.

[29] Moreira, J., Lourida, A., Troncosa, J. S. (2008): Diversity and distribution of Peracarid Crustaceans in shallow subtidal soft bottom at the Ensenada de Baiona (Galicia, NW Spain). - Crustaceana 81(9): 1069-1089. DOI: 101163/156854008X360.

[30] Mutlu, E. (2020): Macrozoobenthic communities on three different ecological statuses of the habitats in the Cilician shelf soft-bottoms. - Journal of Applied Biological Sciences 14(2): 155-189.

[31] Öktener, A., Trilles, J. P. (2004): Report on cymothoids (Crustacea, Isopoda) collected from marine fishes in Turkey. - Acta Adriatica 45(2): 145-154.

[32] Onuk, N. T., Tezer, A. (2017): Analyzing İstanbul Coastline Changes due to Legal Arrangements between 1852 and 2011. - In: Rodriguez, G. R., Brebbia, C. A., Almorza, D. (eds.) Coastal Cities and Their Sustainable Future II. WIT Press, Southampton.

[33] Orhon, D. (1995): Evaluation of the impact from the Black Sea on the pollution of the Marmara Sea. - Water Science \& Technology 32(7): 191-198. DOI: 10.1016/02731223(96)00064-9.

[34] Porter, M. L. (2016): Collecting and processing Mysids, Stygiomysids, and Lophogastrids. - Journal of Crustacean Biology 36(4): 592-595. DOI: 10.1163/1937240X-00002443.

[35] Secrieru, D. and Oaie, G. (2009): The relation between the grain size composition of the sediments from the NW Black Sea and their total organic carbon (TOC) content. - GeoEco-Marina 15: 5-11.

[36] Sezgin, M., Aydemir, Çil, E. (2010): Rocky bottom crustacean fauna of Sinop (Black Sea, Turkey) coast. - Zool Baetica 21: 5-14.

[37] Siegel, S. (1956): Nonparametric Statistics for the Behavioral Sciences - McGraw-Hill, New York.

[38] Sowinsky, W. (1897): Les Crustacés supérieurs (Malacostraca) du Bosphore d'aprés les matériaux recueillis par Mr le Dr AA Ostrooumow I Amphipoda et Isopoda. - Mémoires de la Société des Naturalistes de Kiev 15: 447-518 (in Russian).

[39] Soyer, T. (1970): Bionomie benthique du plateau continental de la cote catalana Française III: Les peuplements de Copepodes Harpacticoides (Crustacea). - Vie Millieu 21: 377-511.

[40] Thiel, M., Hinojosa, I. (2009): Peracarida- Amphipods, Isopods, Tanaidaceans \& Cumaceans, V Häussermann. - In: Förstera, G. (ed.) Fauna marina bentónica de la Patagonia chilena. Nature in Focus, Santiago de Chile.

[41] Topaloğlu, B., Kihara, K. (1993): Community of Mediterranean mussel Mytilus galloprovincialis Lamarck, 1819 in the Bosphorus Strait. - Journal of Tokyo University of Fisheries 80: 113-120.

[42] Usluer, H. B., Alkan, G. (2016): Importance of the marine science and charting about environmental planning, management and policies at the Turkish Straits. - European Journal of Sustainable Development Research 1(1): 16-25.

[43] Uysal, A., Yüksek, A., Okuş, E., Yılmaz, A. (2002): Benthic community structure of the Bosphorus and surrounding area. - Water Science and Technology 46: 37-44. DOI: 102166/wst20020140.

[44] Ünlüata, U., Oğuz, T., Latif, M. A., Özsoy, E. (1990): The Physical Oceanography of Sea Straits - Kluwer, Dortrecht. 
[45] Wang, C. F., Ren, X. Q., Xu, R. L. (2010): Composition, abundance, and diversity of the peracarida on different vegetation types in the Qi'ao-dan'gan Island mangrove nature reserve on qi'ao 1sland in the pearl river estuary, China. - Zoological Studies 49(5): 608615 .

[46] Zaabar, W. F., Cheikhrouha, C., Achouri, M. S. (2017): Distribution of four isopod (Peracarida: Crustacea) in shallow waters of the Bizerte Lagoon (Tunisia, SW Mediterranean Sea). - The European Zoological Journal 84(1): 368-379. DOI: 101080/2475026320171341556.

[47] Zar, J. H. (1984): Biostatistical Analysis. 2nd Ed. - Prentice-Hall, Inc, Englewood Cliffs, NJ. 